\title{
Energy Map of Southwestern Wyoming, Part B-Oil and Gas, Oil Shale, Uranium, and Solar
}

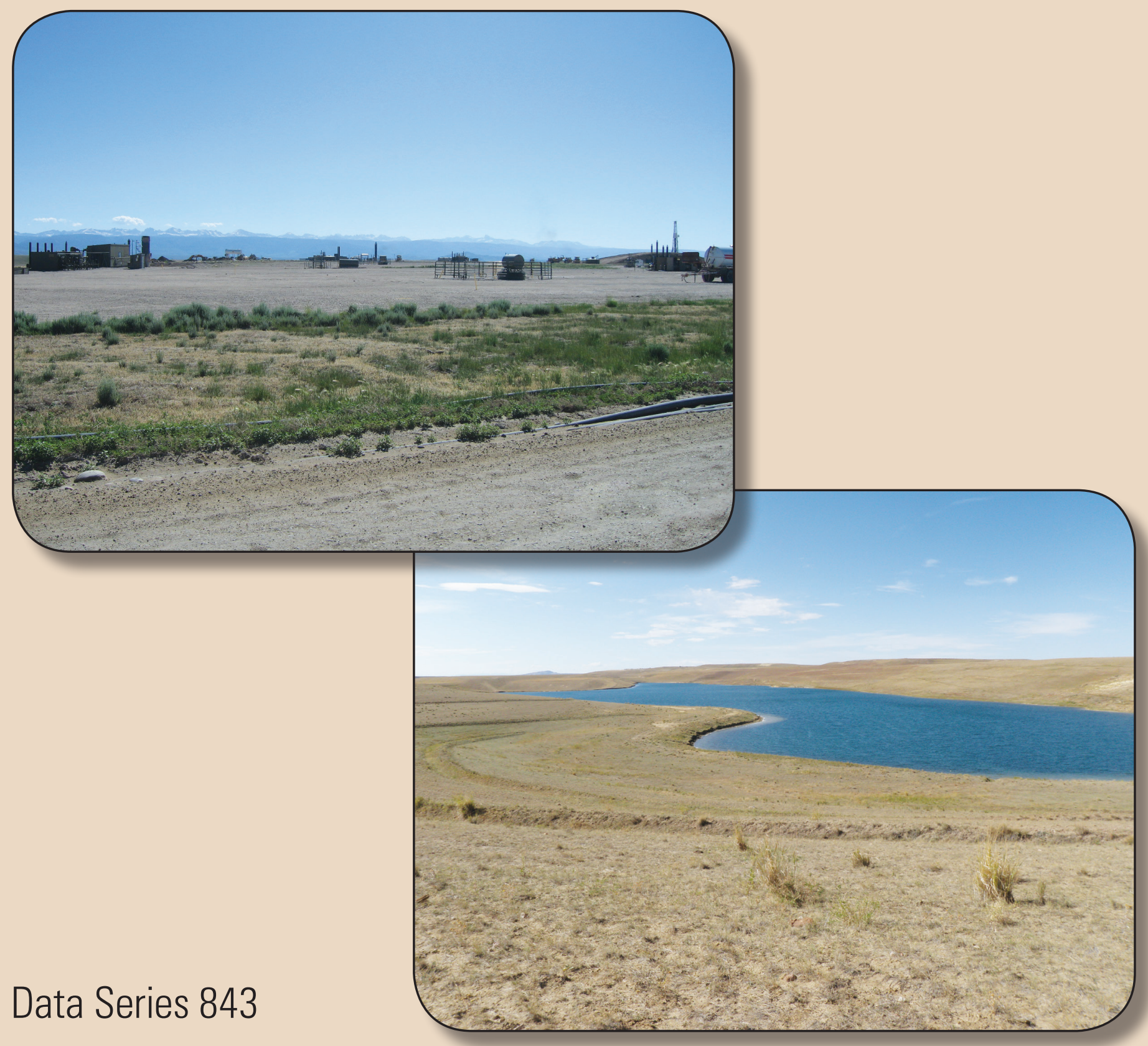

U.S. Department of the Interior

U.S. Geological Survey 
Cover. Top: Pinedale Field, Wind River Mountain Range in the distance. Photograph by Laura R.H. Biewick, 2011.

Bottom: Walker Jenkins Lake (Wyoming Game and Fish Department, public access area) is a former open pit uranium mine in the Shirley Basin. The reclaimed land and lake (100 acres) are on BLM, private, and State Trust Lands.

Photograph by Anna Wilson, 2009. 


\section{Energy Map of Southwestern Wyoming, Part B-Oil and Gas, Oil Shale, Uranium, and Solar}

By Laura R.H. Biewick and Anna B. Wilson

Data Series 843 


\title{
U.S. Department of the Interior SALLY JEWELL, Secretary
}

\section{U.S. Geological Survey Suzette M. Kimball, Acting Director}

\author{
U.S. Geological Survey, Reston, Virginia: 2014
}

For more information on the USGS - the Federal source for science about the Earth, its natural and living resources, natural hazards, and the environment, visit http://www.usgs.gov or call 1-888-ASK-USGS.

For an overview of USGS information products, including maps, imagery, and publications, visit http://www.usgs.gov/pubprod

To order this and other USGS information products, visit http://store.usgs.gov

Any use of trade, firm, or product names is for descriptive purposes only and does not imply endorsement by the U.S. Government.

Although this information product, for the most part, is in the public domain, it also may contain copyrighted materials as noted in the text. Permission to reproduce copyrighted items must be secured from the copyright owner.

Suggested citation:

Biewick, L.R.H., and Wilson, A.B., 2014, Energy map of southwestern Wyoming, Part B-Oil and gas, oil shale, uranium, and solar: U.S. Geological Survey Data Series 843, 20 p., 4 pls., http://dx.doi.org/10.3133/ds843. 


\section{Contents}

List of Acronyms and Affiliated Web Sites
Abstract
Introduction
Oil and Gas
Oil Shalergy Corridor
Uranium
Solar
Gographic Information System (GIS) Layer Information
Summary.
Acknowledgments
References

\section{Figures}

1. Laramide sedimentary and structural basins and intervening uplifts in the Rocky Mountain region extending from southern Montana to northern New Mexico

2. Map of southwestern Wyoming showing the location of large cumulative production gas fields in the WLCl, as of Oct. 3, 2012.

3. Map of southwestern Wyoming showing the location of large cumulativeproduction oil fields in the $\mathrm{WLCl}$, as of Oct. 3, 2012

4. Map of southwestern Wyoming and surrounding areas showing the location of the $\mathrm{WLCl}$ study area in relation to three recently assessed USGS oil and gas provinces

5. Generalized stratigraphic column for southwestern Wyoming .......................................

6. Map of the Green River Formation oil-shale bearing rocks in the Piceance, Uinta, and Greater Green River Basins

7. Map of uranium mineralized areas within the WLCl study area ....................................11

8. Map showing direct-normal solar resource estimates for Wyoming................................13

\section{Table}

1. Layer Information, described by their order in the GIS map files (MXD and PMF), table of contents (58" $\left.\times 39^{\prime \prime}\right)$

\section{Plates}

1. Energy Map of Southwestern Wyoming, Part B: Oil and Gas, Oil Shale, Uranium, and Solar $(36 "$ x 40") .............................................................................. Link

2. The largest oil and gas fields in southwestern Wyoming $\left(40^{\prime \prime} \times 29^{\prime \prime}\right)$........................ Link

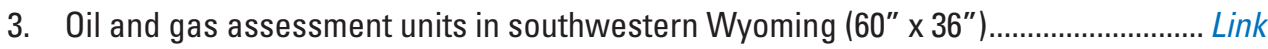

4. Historical perspective of load-claim density 1976-2010, and location of uranium mines, prospects, occurrences, and mineralized areas (29" x 25") 


\section{Conversion Factors}

Inch/Pound to SI

\begin{tabular}{|c|c|c|}
\hline Multiply & By & To obtain \\
\hline \multicolumn{3}{|c|}{ Length } \\
\hline foot $(\mathrm{ft})$ & 0.3048 & meter $(\mathrm{m})$ \\
\hline \multicolumn{3}{|c|}{ Area } \\
\hline square mile $\left(\mathrm{mi}^{2}\right)$ & 2.590 & square kilometer $\left(\mathrm{km}^{2}\right)$ \\
\hline \multicolumn{3}{|c|}{ Mass } \\
\hline ton, short $(2,000 \mathrm{lb})$ & 0.9072 & megagram (Mg) \\
\hline ton, long $(2,240 \mathrm{lb})$ & 1.016 & megagram (Mg) \\
\hline \multicolumn{3}{|c|}{ Volume } \\
\hline barrel (bbl), (petroleum,1 barrel=42 gal) & 0.1590 & cubic meter $\left(\mathrm{m}^{3}\right)$ \\
\hline cubic foot $\left(\mathrm{ft}^{3}\right)$ & 0.02832 & cubic meter $\left(\mathrm{m}^{3}\right)$ \\
\hline \multicolumn{3}{|c|}{ Energy } \\
\hline kilowatt hour (kWh) & $3,600,000$ & joule $(\mathrm{J})$ \\
\hline megawatt hour (MWh) & 3,600 & megajoule (MJ) \\
\hline
\end{tabular}

SI to Inch/Pound

\begin{tabular}{lcl}
\hline & Mass & \\
\hline megagram (tonne) $(\mathrm{Mg})$ & 1.102 & ton, short $(2,000 \mathrm{lb})$ \\
megagram (tonne) $(\mathrm{Mg})$ & 0.9842 & ton, long $(2,240 \mathrm{lb})$ \\
\hline
\end{tabular}

British thermal unit (Btu) - The amount of heat needed to raise the temperature of 1 pound of water by 1 degree Fahrenheit.

Temperature in degrees Celsius $\left({ }^{\circ} \mathrm{C}\right)$ may be converted to degrees Fahrenheit $\left({ }^{\circ} \mathrm{F}\right)$ as follows:

$$
{ }^{\circ} \mathrm{F}=\left(1.8 x^{\circ} \mathrm{C}\right)+32
$$

Temperature in degrees Fahrenheit $\left({ }^{\circ} \mathrm{F}\right)$ may be converted to degrees Celsius $\left({ }^{\circ} \mathrm{C}\right)$ as follows: ${ }^{\circ} \mathrm{C}=\left({ }^{\circ} \mathrm{F}-32\right) / 1.8$

Horizontal coordinate information is referenced to the North American Datum of 1983 (NAD 83). 


\section{List of Acronyms and Affiliated Web Sites}

AU

BLM

DOD

DOE

DOI

EIA

Esri

GIS

NREL

PEIS

SRRL

TPS

USDA

USFS

USGS

USGS CERSC

U.S.NRC

WLCI

WOGCC

Assessment unit, U.S. Geological Survey, Energy Resources Program, National Oil and Gas Assessment http://energy.usgs.gov/OilGas/AssessmentsData/NationalOilGasAssessment.aspx

U.S. Bureau of Land Management (part of the Department of the Interior) http://www.blm.gov/

U.S. Department of Defense http://Www.defense.gov/

U.S. Department of Energy http://energy.gov/

U.S Department of the Interior http://www.doi.gov/

U.S. Energy Information Administration (part of the U.S. Department of Energy) http://www.eia.gov/

Environmental Systems Research Institute, Inc. http://www.esri.com

Geographic Information System

U.S. National Renewable Energy Laboratory (part of the U.S. Department of Energy) http://www.nrel.gov/

Programmatic Environmental Impact Statement http://solareis.anl.gov/documents/fpeis/index.cfm

Solar Radiation Research Laboratory (part of the National Renewable Energy Laboratory, NREL) http://www.nrel.gov/solar_radiation/

Total Petroleum System, U.S. Geological Survey, Energy Resources Program, http://energy.usgs.gov

U.S. Department of Agriculture http://www.usda.gov/wps/portal/usda/usdahome

U.S. Forest Service (part of the Department of Agriculture) http://www.fs.fed.us/

U.S. Geological Survey (part of the Department of the Interior) http://www.usgs.gov/

U.S. Geological Survey Central Energy Resources Science Center http://energy.usgs.gov/GeneralInfo/ScienceCenters/Central.aspx

WSGS Wyoming State Geological Survey http://www.wsgs.uwyo.edu/ 



\title{
Energy Map of Southwestern Wyoming, Part B- Oil and Gas, Oil Shale, Uranium, and Solar
}

\author{
By Laura R.H. Biewick and Anna B. Wilson
}

\begin{abstract}
The U.S. Geological Survey (USGS) has compiled Part B of the Energy Map of Southwestern Wyoming for the Wyoming Landscape Conservation Initiative (WLCI). Part B consists of oil and gas, oil shale, uranium, and solar energy resource information in support of the WLCI. The WLCI represents the USGS partnership with other Department of the Interior Bureaus, State and local agencies, industry, academia, and private landowners, all of whom collaborate to maintain healthy landscapes, sustain wildlife, and preserve recreational and grazing uses while developing energy resources in southwestern Wyoming. This product is the second and final part of the Energy Map of Southwestern Wyoming series (also see USGS Data Series 683, http://pubs.usgs.gov/ds/683/), and encompasses all of Carbon, Lincoln, Sublette, Sweetwater, and Uinta Counties, as well as areas in Fremont County that are in the Great Divide and Green River Basins.
\end{abstract}

\section{Introduction}

To further advance the objectives of the Wyoming Landscape Conservation Initiative (WLCI), the U.S. Geological Survey (USGS) has compiled Part B of the Energy Map of Southwestern Wyoming, to include oil and gas, oil shale, uranium, and solar resource potential. Part A (USGS Data Series 683, http://pubs.usgs.gov/ds/683/) focused primarily on the electrical power sources of coal and wind (Biewick and Jones, 2012).

Although much of the material presented in this report is based on published data, the information was never assembled in one place or presented in a way that relates various energy resource commodities, infrastructure, and restrictions or impediments to resources development. Parts A and B of the Energy Map of Southwestern Wyoming provide energy resources data assembled in a Geographic Information System (GIS) data package. Part B includes: (1) USGS oil and gas assessment units (AUs) that define areas of undiscovered technically recoverable oil and natural gas (table 1); (2) uranium deposits and related features (Wilson, in press); (3) infrastructure associated with oil and gas exploration, production and development (De Bruin, 2007); (4) proposed corridors for pipelines and electricity transmission and distribution facilities
(U.S. Department of Energy and others, 2010); (5) USGS in-place oil shale resource assessment data (Brownfield and others, 2008; Dyni and others, 2008; Johnson, Mercier, and Brownfield, 2011; Johnson, Mercier, Ryder and others, 2011; Mercier and others, 2011; U.S. Geological Survey Oil Shale Assessment Team, 2011; and Birdwell and others, 2013); (6) the extent and nature of restrictions or impediments to oil and gas resources development (U.S. Departments of the Interior, Agriculture, and Energy, 2006); and (7) an oil and gas wells geodatabase.

In addition, the U.S. Bureau of Land Management (BLM) oil and gas sale parcels, and leasing and unit agreements (BLM, 2010); solar resources (U.S. Department of Energy, National Renewable Energy Laboratory (NREL), 2010); ArcGIS Online services (Environmental Systems Research Institute, Inc. (Esri), 2010) and other base layers are embedded in the energy map (pl. 1). Energy maps, data, documentation and spatial data processing capabilities are available in a geodatabase (Esri, 2012), published map file (a PMF) (Esri, 2008a); ArcMap document (an MXD), (Esri, 2000); Adobe Acrobat PDF map (Adobe Systems Incorporated, 2010) and other digital products that can be downloaded at the USGS website (http://dx.doi.org/10.3133/ds843). Users can compare the locations of the largest gas fields (from De Bruin, 2007; Wyoming Oil and Gas Conservation Commission (WOGCC, 2012) with associated processing and energy transport corridors (from De Bruin, 2007); and view relationships with the USGS estimates of undiscovered technically recoverable oil and natural gas resources (from USGS Southwestern Wyoming Province Assessment Team, 2002; USGS Wyoming Thrust Belt Assessment Team, 2004; Dyman and others, 2005). Users can also view the nature and extent of development limitations on these resources (from U.S. Departments of the Interior, Agriculture, and Energy, 2006).

Accompanying the energy map, Part B (pl. 1) and the geospatial data are three additional plates describing the geology and energy resources. These plates include production information for the largest oil and gas fields (pl. 2), geologic information regarding the oil and gas assessment units (pl. 3), and uranium resources material (pl. 4). Hyperlinks embedded in plates 2 through 4 associate the information to source publications and data on the Internet. The plates can be printed, or accessed digitally as Adobe PDF files, or viewed in Excel (Microsoft, 2007), where frozen panes retain headings in large 
spreadsheet-style plates. The data represent decades of research by the USGS, Wyoming State Geological Survey (WSGS), BLM, private industry, and others and facilitates science-based assessments and resource management decisions.

\section{Oil and Gas}

The Laramide sedimentary basins in Wyoming contain some of the largest fossil fuel accumulations in the United States (U.S. Energy Information Administration (EIA), 2010; fig. 1).

Records indicate that oil seeps were discovered in western Wyoming at the time of the great westward migration in the mid-1800s. Oil production began in the 1880s, and fields were developed in major basins of Wyoming (WSGS, 2011). The Wyoming gas industry developed more slowly (De Bruin, 2001), and it was not until 1955 that yearly natural gas production in Wyoming topped 100 billion cubic feet of natural gas (BCFG). The $500 \mathrm{BCFG}$ production milestone was not reached until 1983, whereas the 1 trillion cubic feet (TCFG) benchmark was reached rather quickly in 1992, due in large part to major discoveries in the western Wyoming thrust belt. Southwestern Wyoming has 15 of the Nation's 100 largest oil and gas fields, including Pinedale (third) and Jonah (seventh) natural gas fields (EIA, 2009a). In 2010, Wyoming ranked second (only to Texas) in marketed natural gas production of 2.3 TCF (EIA, 2011a). Wyoming ranked second for total domestic energy production of 10,337 trillion Btu in 2009 (EIA, 2011a). The Btu (British thermal unit) is the amount of heat needed to raise the temperature of 1 pound of water by 1 degree Fahrenheit. The Btu is a convenient measure by which to compare the energy content of various fuels.

In southwestern Wyoming, oil and natural gas are produced from reservoirs ranging in age from Precambrian (Lost Soldier) to Eocene (Big Piney), and only excludes the Silurian period (De Bruin, 2007) (fig. 2). Some of the largest gas producing fields in the WLCI area, based on cumulative gas production values as of Oct. 3, 2012 (WOGCC, 2012) include:

\section{Jonah field (3.74 TCFG)}

2. Pinedale field (3.66 TCFG)

3. Wamsutter area basin-centered gas fields (eastern Sweetwater County and western Carbon County)

4. La Barge platform and Moxa arch gas fields (western Sweetwater County, eastern Lincoln and Uinta Counties, and southwestern Sublette County)

By comparison, cumulative production from the largest gas basin in Wyoming, the Powder River Basin (PRB), is 5 TCF of coalbed gas (WOGCC, 2012).

Although the southwest Wyoming area is primarily a natural gas province, significant oil reserves are also found (De Bruin, 2007). Based on cumulative oil production as of Oct. 3, 2012 (WOGCC, 2012), the largest oil fields, include those shown in fig. 3.
Plate 2 contains information on the largest producing oil and gas fields in the study area, including field production graphs from the WOGCC illustrating historical production trends from 1978 to October 2012. Monthly production of oil and water is reported in barrels (bbl); gas production is reported in thousand cubic feet (MCF). For example, the Pinedale field was discovered in 1955 and historical production information is available from the WOGCC starting in 1983. During the first decade, recorded production fluctuations appeared to be in the tens of millions of cubic feet of gas per month, and hundreds of barrels of oil. Water production appeared to be less than $100 \mathrm{bbl}$ per month. From 1997 to 2001, production increased and fluctuations appeared to be smaller than during previous years. After 2001, gas production stayed above 1 billion cubic feet (BCFG) per month, and reached $10 \mathrm{BCFG}$ per month in 2004. The last 8 years of production showed a steady increase that has leveled off, and production has been constant for the last 4 years between 40 and 50 BCFG per month. A similar pattern is shown in oil and water production. The Pinedale data included about 2,000 producing wells, with about 100 wells shut-in or with suspended operations. The Jonah field has a pattern somewhat similar to Pinedale in that production increased until 2008 at which time it leveled off for several years and appears to have declined slightly in the last two years.

In Wertz field, one of the top oil-producing fields, production has ranged from 400 thousand barrels (MBBLS) per month in 1988 to 20 MBBLS per month in 1999. Today's production is nearly 70 MBBLS per month. The largest oil-producing field, Lost Soldier, has fluctuated over a 34-year period, with a high of approximately 500 MBBLS per month in 1979 and 1995, and current production levels over 100 MBBLS per month.

The USGS Central Energy Resources Science Center (CERSC) continues to assess the potential for undiscovered oil and gas resources in priority geologic provinces in the United States and other parts of the world. In the early to mid-2000s, the CERSC National Assessment of Oil and Gas Resources Team estimated the undiscovered oil and gas resources in the three provinces that encompass the WLCI study area (fig. 4). The approach evaluated the framework geology, defined total petroleum systems (TPS), delineated assessment units (AU) within the total petroleum systems, and, used a peerreviewed statistical methodology to assess the technically recoverable, undiscovered petroleum resources in each AU (pl. 3). The combined undiscovered resource estimates for the Southwestern Wyoming; the Wyoming Thrust Belt; and the Hanna, Laramie, and Shirley Basins Provinces were a statistical mean of 85.8 trillion cubic feet (TCFG) of natural gas; a statistical mean of 264 million barrels of oil (MMBO); and a statistical mean of 2.7 billion barrels of natural gas liquids (BBNGL), most of which are in the Southwestern Wyoming Province (USGS Southwestern Wyoming Province Assessment Team, 2002; USGS Wyoming Thrust Belt Province Assessment Team, 2004; Dyman and others, 2005). Even though the three provinces extend beyond the WLCI boundary, large portions of the oil and gas resources are expected to reside within the WLCI area. 


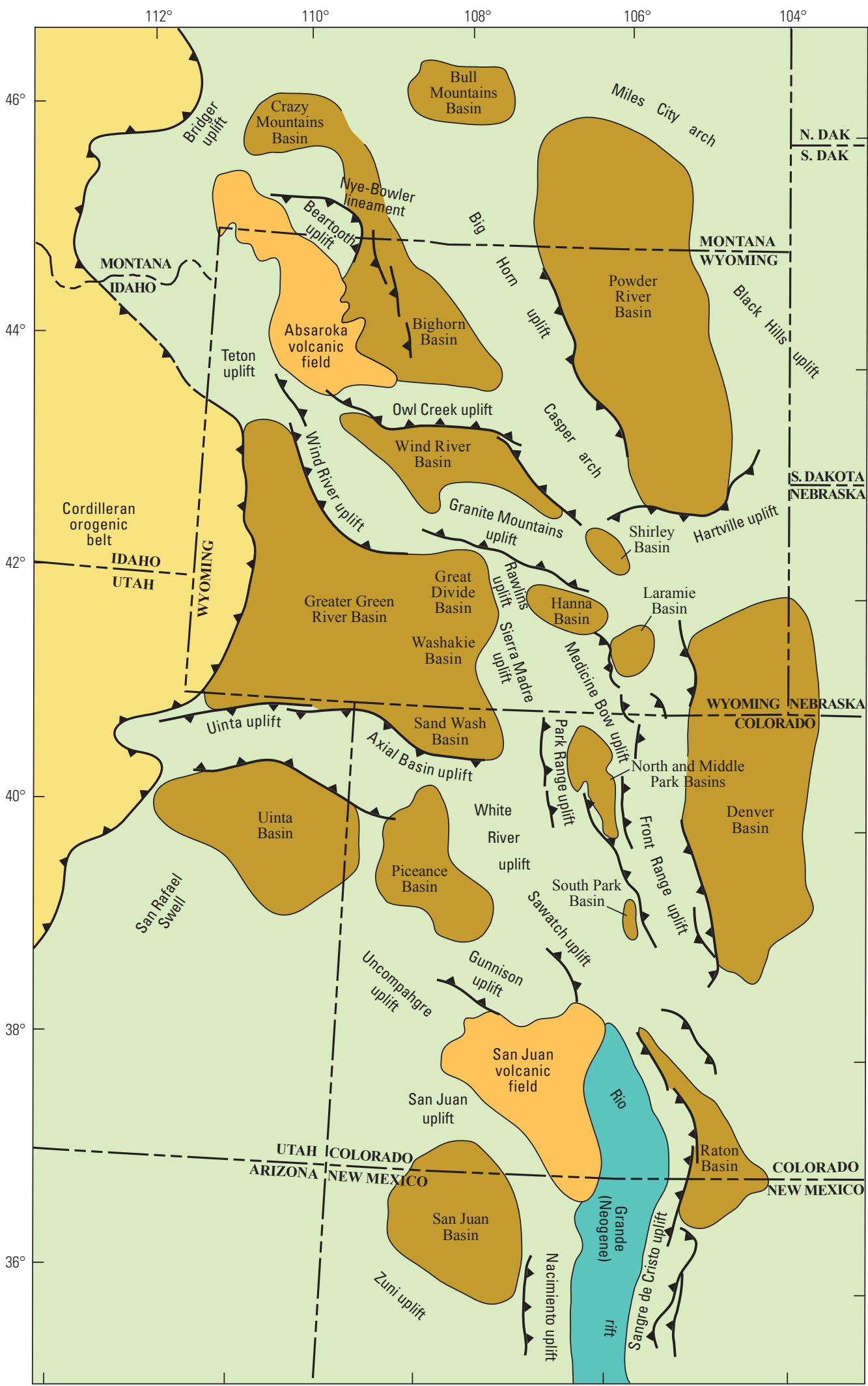

EXPLANATION

스는 Thrust or reverse fault

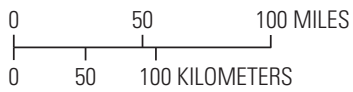

Figure 1. Laramide sedimentary and structural basins and intervening uplifts in the Rocky Mountain region extending from southern Montana to northern New Mexico. Modified from Dickinson and others (1988). 


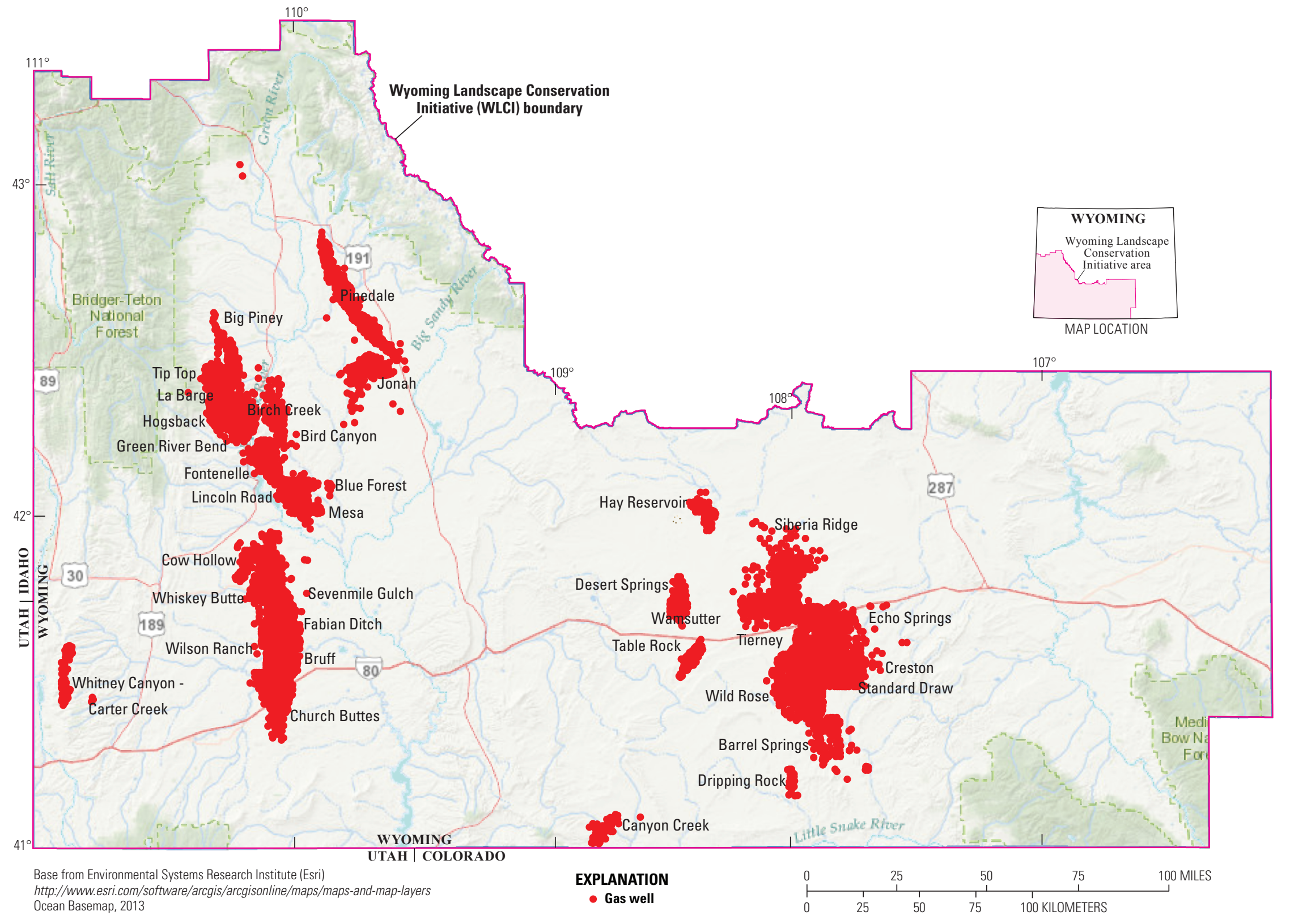

Figure 2. Map of southwestern Wyoming showing the location of large cumulative production gas fields in the WLCl, as of Oct. 3, 2012 (WOGCC, 2012). 


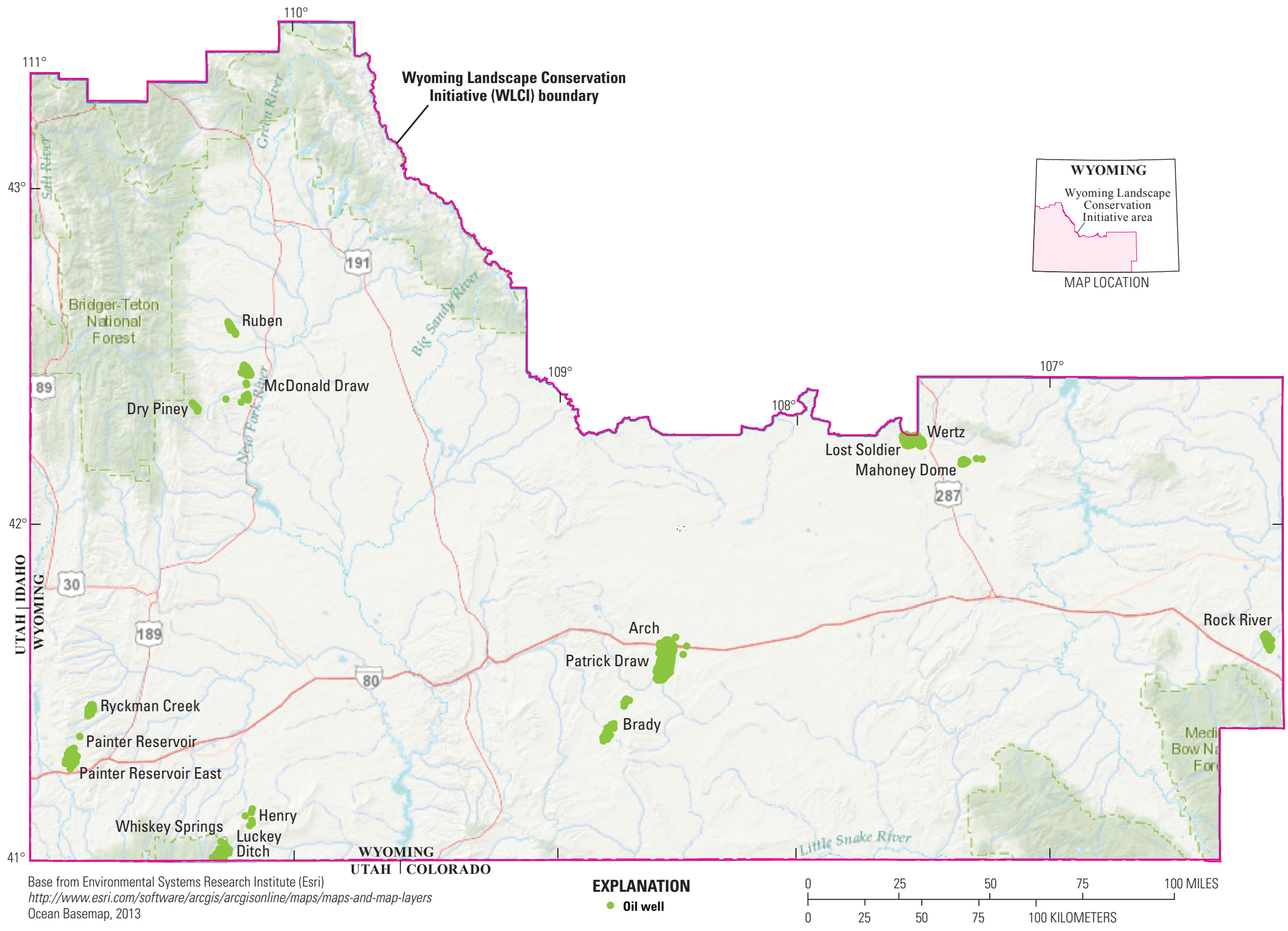

Figure 3. Map of southwestern Wyoming showing the location of large cumulative-production oil fields in the WLCl, as of Oct. 3, 2012 (WOGCC, 2012). 


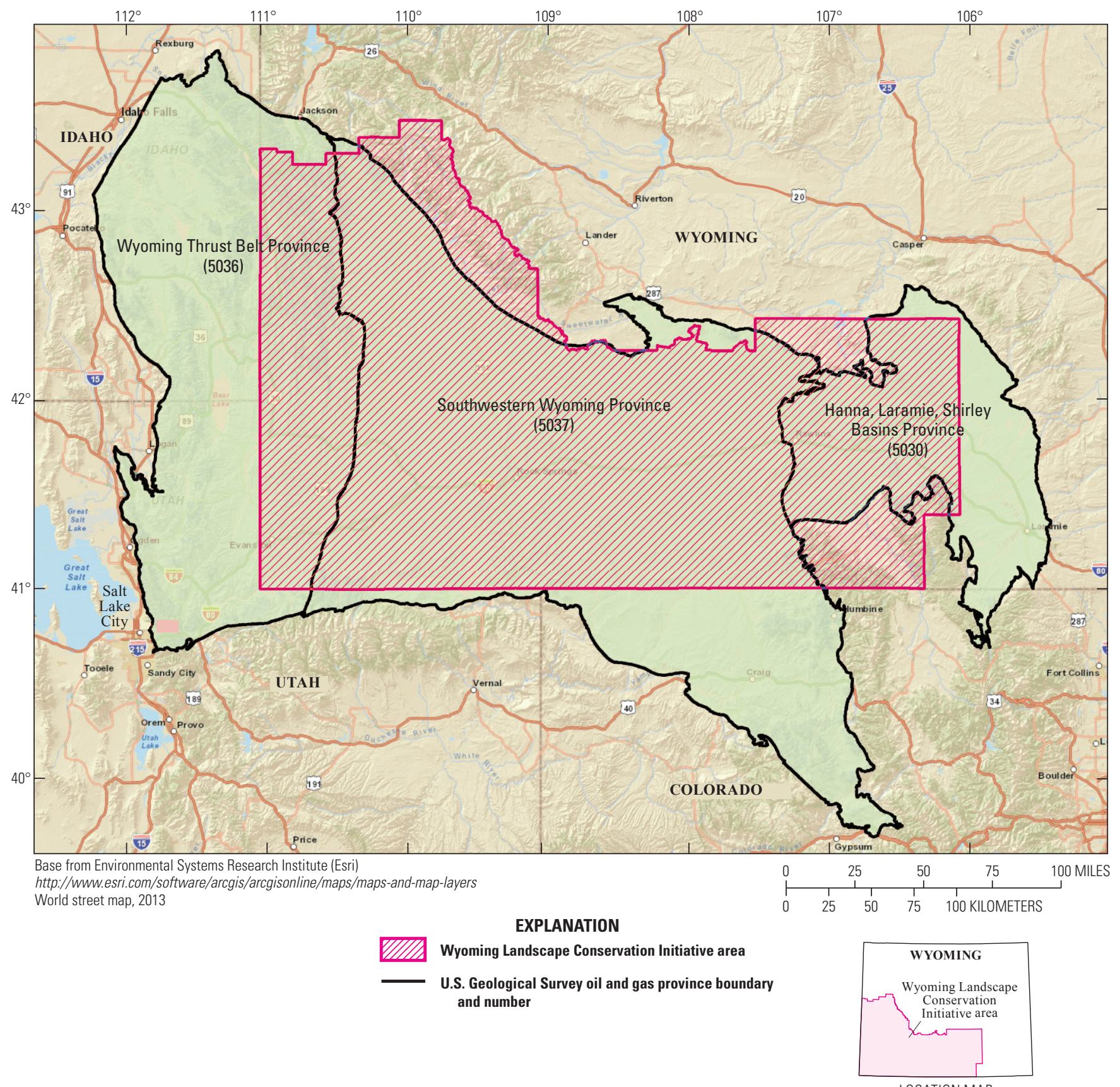

LOCATION MAP

Figure 4. Map of southwestern Wyoming and surrounding areas showing the location of the WLCl study area in relation to three recently assessed USGS oil and gas provinces and their assigned province numbers (in parenthesis). 
The primary source rocks in the study area range in age from the Permian Phosphoria Formation (271 Ma) to the Eocene Green River Formation (52.5 to $47.5 \mathrm{Ma}$ ). They include: (1) black marine shale of the Lower Permian Phosphoria Formation; (2) coaly and lacustrine facies of the Bear River and Frontier Formations and Dakota Sandstone; (3) marine shale units of the Cretaceous Mowry and Thermopolis Shales; (4) thick shale beds of the Hilliard and Baxter Shales; (5) clay-rich marine shale and calcareous-rich zones in the Niobrara Formation; (6) coal within the Mesaverde Group; (7) marine mudrock in the Lewis Shale; (8) coal and carbonaceous shale in the Upper Cretaceous Lance and Paleocene Fort Union Formations; and (9) shale and coal in the (mostly) Eocene Wasatch and Green River Formations (fig. 5). Productive reservoirs span a variety of geologic depositional environments including: fluvial, tidal, deltaic, and shoreface sandstone reservoirs; fractured, calcareous shale, limestone, and marl; and turbidites (USGS Southwestern Wyoming Province Assessment Team, 2005a; pl. 3).

The pace of domestic shale-gas research, exploration, and development has increased across the country in recent years. The Wyoming State Geological Survey is carrying out shale-gas investigations on the Upper Cretaceous Mowry Shale, a major source rock in the northern Rocky Mountain region. Extensively distributed throughout Wyoming's Laramide basins, the Mowry Shale and its equivalents consists of organic-rich, fine-grained siliciclastic rocks and has considerable potential to produce gas (Surdam and others, 2010). Seventy-five miles south of Rock Springs, in the Vermillion Basin of the Greater Green River Basin, Questar Corp. announced a 9-MMCF-per-day well producing from another shale play that overlies the Mowry Shale: the Baxter Shale and the Frontier Formation (Brown, 2007). The middle member of the Baxter Shale appears to be the major contributor to production; however, other intervals also contribute (Hill and others, 2008).

\section{Energy Corridor}

Wyoming, with its vast resources and production, is a transportation crossroads for Canadian crude oil imports and local Rocky Mountain production flowing to U.S. Midwest and surrounding markets (EIA, 2010). A major pipeline corridor extending across the WLCI area and roughly parallel to U.S. Interstate 80 transports the majority of Wyoming's gas supply from large fields to local and regional markets, as well as to California. Mapped pipelines, oil refineries, and natural gas processing plants shown in this report originated from the oil and gas map of Wyoming (De Bruin, 2007). Oil production from this area is processed both locally, at the refinery in Sinclair, and in out-of-state facilities (De Bruin, 2007). As a result of increasing production, there are proposals to expand the energy corridor. One such proposal is the west-wide energy corridor.

The proposed location of the southwestern Wyoming portion of the west-wide energy corridor is included in this report and derived from the U.S. Department of Energy's online information center (http://corridoreis.anl.gov/eis/fmap/index.cfm).
The west-wide energy corridors were proposed under the requirements of Section 368 of the Energy Policy Act of 2005 (42 USC 15801 note, http://www.gpo.gov/fdsys/pkg/PLAW109publ58/html/PLAW-109publ58.htm), which directs the secretaries of Agriculture, Commerce, Defense, Energy, and Interior to designate these corridors on Federal lands in 11 western states, including Wyoming, for oil, gas, and hydrogen pipelines, and electrical transmission and distribution facilities (http://corridoreis.anl.gov/documents/fpeis/voll/ WWEC_FPEIS_FrontI.pdf).

This act requires a scientific inventory of onshore Federal lands' oil and gas resources and the extent and nature of restrictions or impediments to their development. Phase II cumulative inventory consists of: northern Alaska, Montana thrust belt, Powder River Basin, Wyoming thrust belt, Greater Green River Basin, Denver Basin, Uinta-Piceance Basin, Paradox/San Juan Basins, Appalachian Basin, Black Warrior Basin, and the Florida peninsula (BLM, 2006, http://www.blm.gov/epca/). To complete the designation of Section 368 energy corridors, the Federal agencies prepared a Programmatic Environmental Impact Statement (PEIS) to analyze the effects of designated energy corridors on Federal lands in 11 western states and to incorporate the designations into relevant land use and resource management plans. There was public interaction and comments on the draft PEIS, and the final PEIS includes many changes and revisions based on comments received (U.S. Department of Energy (DOE) and others, 2010). The geographic information system (GIS) data used to carry out analysis, provide visualization products, generate statistics, support corridor siting, and produce the Map Atlas are from the U.S. Department of Energy and others (2010). Each of these components is included in this report. The data were critical in developing an integrated assessment of energy resources and ecosystems at a landscape level in southwestern Wyoming.

\section{Oil Shale}

The Piceance, Uinta, and Greater Green River Basins in Colorado, Wyoming, and Utah, contain the largest known oil shale deposits in the world, in the Eocene Green River Formation. Wyoming's oil shale deposits are concentrated in the southwestern part of the state in the Green River and Washakie Basins, and are generally lower-grade and lessfavorable deposits for commercial extraction than those in Utah and Colorado (fig. 6).

The USGS completed an assessment of the in-place oil shale resources in the Eocene Green River Formation of the Greater Green River Basin in southwestern Wyoming, northwestern Colorado, and northeastern Utah (Johnson, Mercier, and Brownfield, 2011; Johnson, Mercier, Ryder, and others, 2011). Total in-place resources are estimated at about 1.45 trillion barrels of oil (TBO) divided among three assessed units. Using GIS technology, several derivative products utilizing the 1.45 trillion barrel resource calculations were generated. One product merged the oil shale resource data with BLM surface and subsurface ownership data (BLM, 2011). An estimated 906 billion 


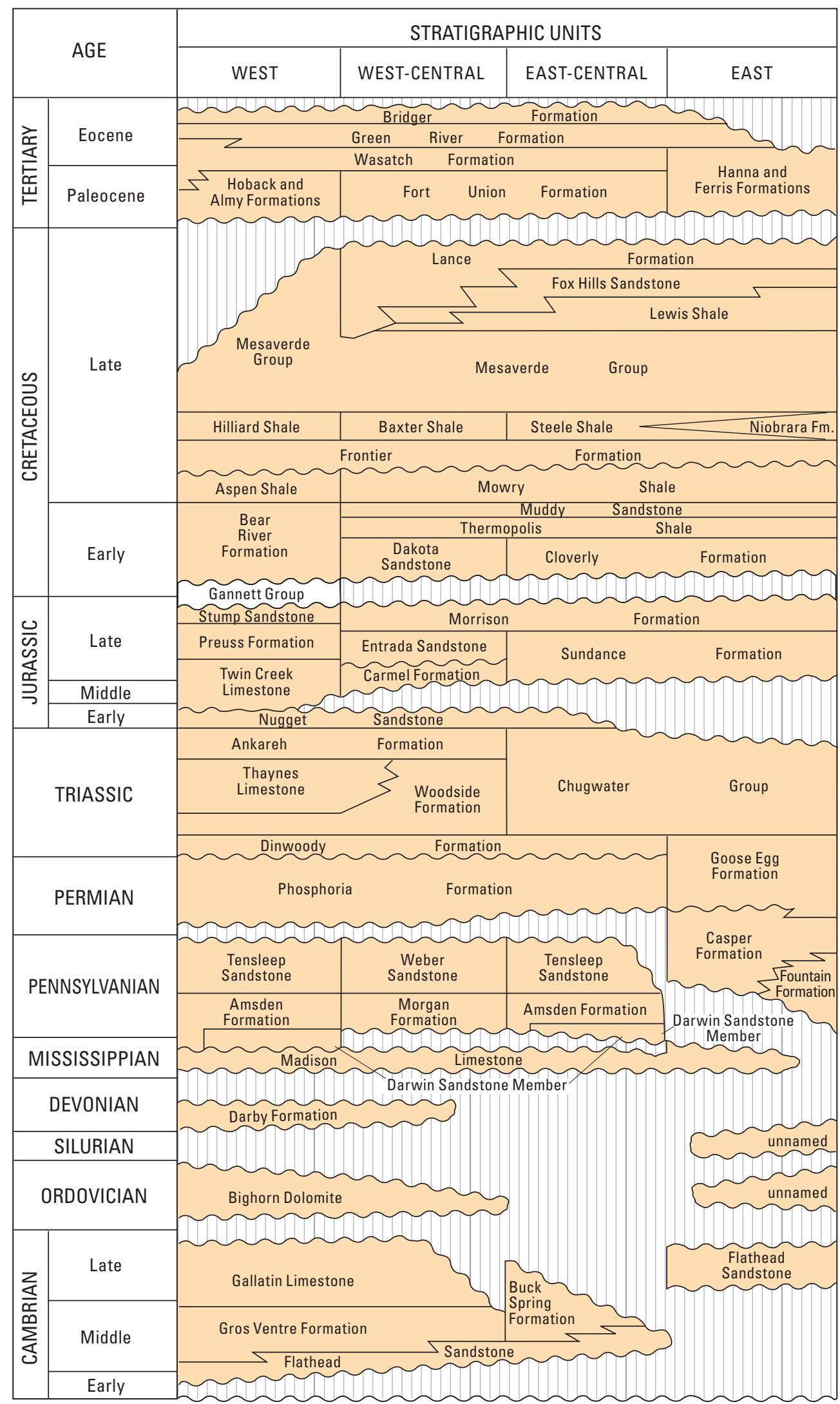

Figure 5. Generalized stratigraphic column for southwestern Wyoming. Modified from USGS Southwestern Wyoming Province Assessment Team (2005a). 


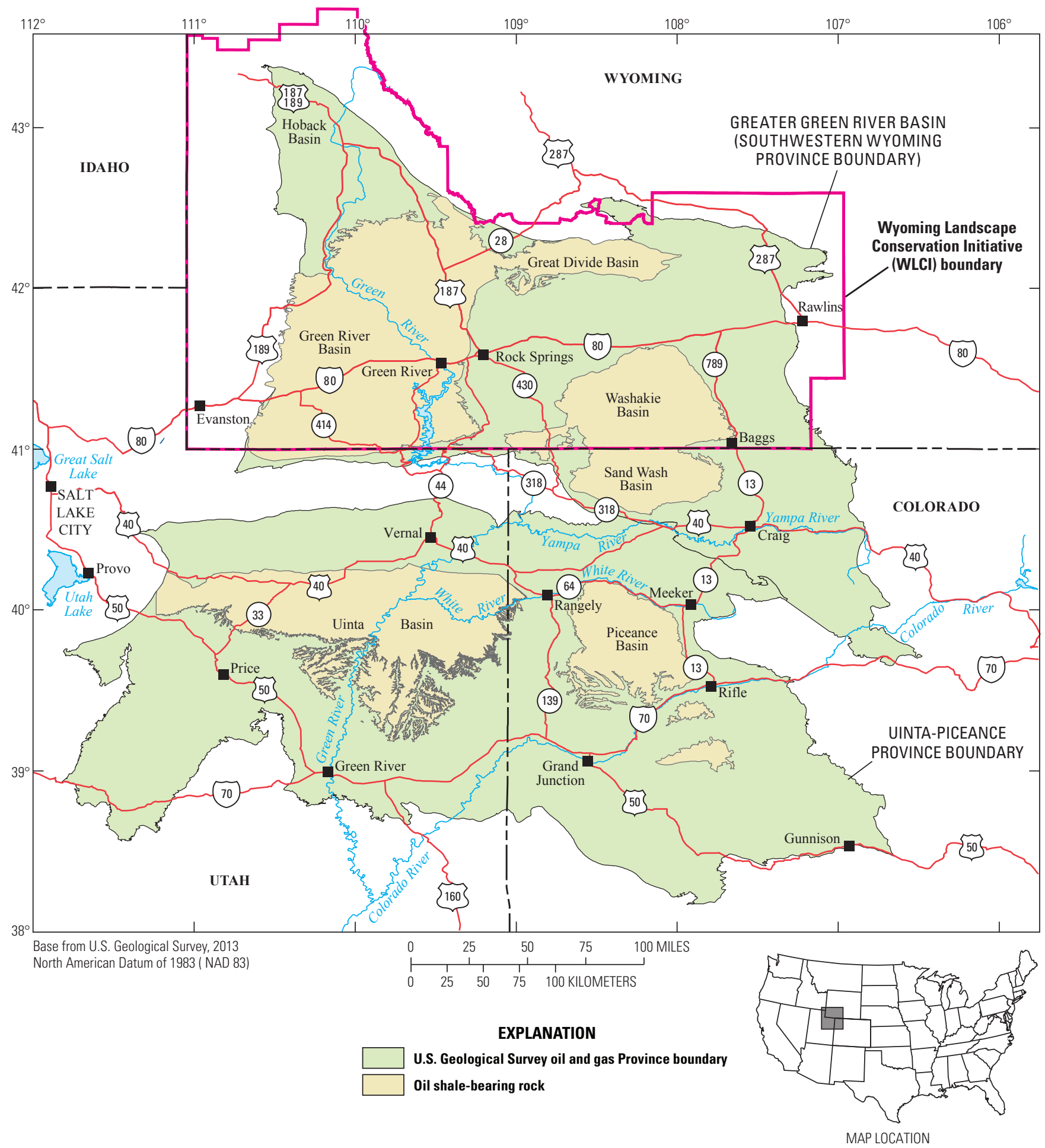

Figure 6. Map of the Green River Formation oil-shale bearing rocks in the Piceance, Uinta, and Greater Green River Basins (from Johnson, Mercier, Ryder, and others, 2011). 
barrels (62 percent) of in-place oil shale resources are Federally owned (Mercier and others, 2011). No attempt was made to estimate the amount of oil that is technically or economically recoverable because it requires temperatures of 280 to $400{ }^{\circ} \mathrm{C}$ or more to extract the oil from an oil shale. Currently, there is no economic method to extract oil from the Green River Formation (Johnson and others, 2009). Theoretical estimates project that a ton of oil shale on average may produce about one-third the energy of a ton of coal, and there are environmental problems because oil shale operations require large amounts of water and may release arsenic, selenium, boron, copper, molybdenum, and barium compounds contained in the Green River Formation oil shale (Johnson and others, 2009).

In addition to the oil shale assessment, the USGS maintains a collection of oil shale information, including geophysical and lithologic logs, water data, chemical and X-ray diffraction analyses on the Green River oil shale deposits in Colorado, Utah, and Wyoming. Because of the increased interest in oil shale, a CD-ROM containing Fischer assay data and oil-yield histograms for the Green River oil shale deposits in southwestern Wyoming was released to the public (Brownfield and others, 2008, available at $h t t p: / / p u b s . u s g s . g o v / o f / 2008 / 1152 /)$. The supporting data are extensive (75.2 megabytes), and include information on 971 core holes and rotary-drilled boreholes and numerous surface sections. The GIS data published in this report include oil shale drill cores and rotary cuttings, structure and overburden isopach maps, and resource assessment results in geospatial data formats created by the USGS Oil Shale Assessment Team (U.S. Geological Survey Oil Shale Assessment Team, 2011).

\section{Uranium}

Wyoming has been the Nation's leading producer of uranium ore since 1995 and has the largest uranium reserves of any state (Wyoming State Geological Survey, 2012b). Uranium mining in Wyoming began in the early 1950s, and peaked in 1979-1980. Since 1991, all of the state's production has been from in-situ recovery (ISR) (Wyoming State Geological Survey, 2012b). Estimates of total statewide cumulative uranium production are on the order of 91,000 tonnes of uranium oxide $\left(\mathrm{U}_{3} \mathrm{O}_{8}\right)$, a milled uranium ore often called "yellow cake," and remaining resources are estimated at about 165,000 tonnes of $\mathrm{U}_{3} \mathrm{O}_{8}$ (Boberg, 2010); or about twice what has already been produced. Total pre-mining endowment statewide would, therefore, be approximately 256,000 tonnes of $\mathrm{U}_{3} \mathrm{O}_{8}$. These values do not include "undiscovered" resources. A quantitative resource assessment of the undiscovered uranium in the WLCI area is beyond the scope of this study.

In 1979, there were 17 operating uranium mines in Wyoming and about 25 planned for development (WSGS, 2012b). Prices and demand for uranium dropped sharply in response to the Three Mile Island incident in Pennsylvania in 1979 and again in 1986, presumably in response to the Chernobyl disaster in the Ukraine (in the former Soviet Union).
Since 1991, all the uranium production in the state has been from the Smith Ranch-Highland ISR in the Powder River Basin (WSGS, 2012b), more than $50 \mathrm{~km}$ (30 mi) northeast of the WLCI study area. As of 2012, there were no producing uranium mines in the WLCI area.

Renewed demand for uranium in the last few years has resulted in increased exploration and development in several areas in and immediately adjacent to the WLCI. Uranium mineralized areas (fig. 7) at Ketchum Buttes, Poison Basin, Shirley Basin, and Great Divide Basin are nearly all within the WLCI, and the southern end of the Crooks Gap-Green Mountain overlaps the northern margin of WLCI.

Most of Wyoming's uranium deposits are in Paleocene and Eocene arkoses and sandstones in Tertiary-aged basins. The roll-front-type uranium deposits were formed when groundwater migrated through the porous and permeable sedimentary rocks (mostly sandstone, arkose, and conglomerate). The groundwater leached uranium from source rocks (such as Precambrian igneous or metamorphic basement rocks, or Paleozoic or Cenozoic volcanic ash-fall deposits) in an oxygenated environment and re-deposited it in a reducing environment (WSGS, 2012a).

In the WLCI study area, most of the uranium deposits are in sedimentary basins; all except Poison Basin and Ketchum Buttes are roll-front types in Eocene (55-34 Ma) sediments. The uranium in Poison Basin is a tabular deposit in younger, Miocene (23-5 Ma) sediments (Dahlkamp, 2010). Host rocks are the Tertiary North Park Formation in Ketchum Buttes; Oligocene and Miocene Browns Park Formation in Poison Basin; Eocene Wind River Formation in Shirley Basin; and the interfingering Eocene Wasatch and Battle Spring Formations in Crooks Gap-Green Mountain and Great Divide Basins (Dahlkamp, 2010). The Battle Spring Formation is temporally equivalent to the Wind River Formation (Boberg, 2010, p.658). The North Park Formation is considered to be equivalent to the upper part of the Browns Park Formation (Gregory and others, 2010).

The USGS maintains the Mineral Resources Database (MRDS, http://mrdata.usgs.gov/mrds/) of mineral districts, deposits, mines, prospects, and mineral occurrences (U.S. Geological Survey, 2012). Site visits to each of the uranium areas in the WLCI over several summers (2008-2010) confirms that most of the sites included in the MRDS database have been abandoned for many decades, and the vast majority of the sites were never developed (A.B. Wilson, USGS, unpublished field notes, 2008-2010). At Ketchum Buttes there was minimal evidence of activity, past or present, other than a small long-abandoned pit. Several small abandoned mine sites and tailings piles were evident in Poison Basin. Activity in Shirley Basin and Crooks Gap-Green Mountain areas is currently limited to reclamation, although there were large operating mines there in the past.

The U.S. Nuclear Regulatory Commission (U.S.NRC) has issued permits for uranium recovery sites at Lost Creek (ISR) and Sweetwater (conventional uranium mine) (U.S.NRC, 2012). Additional information about the Lost Creek project can be found on the BLM website (BLM, 2012a). 


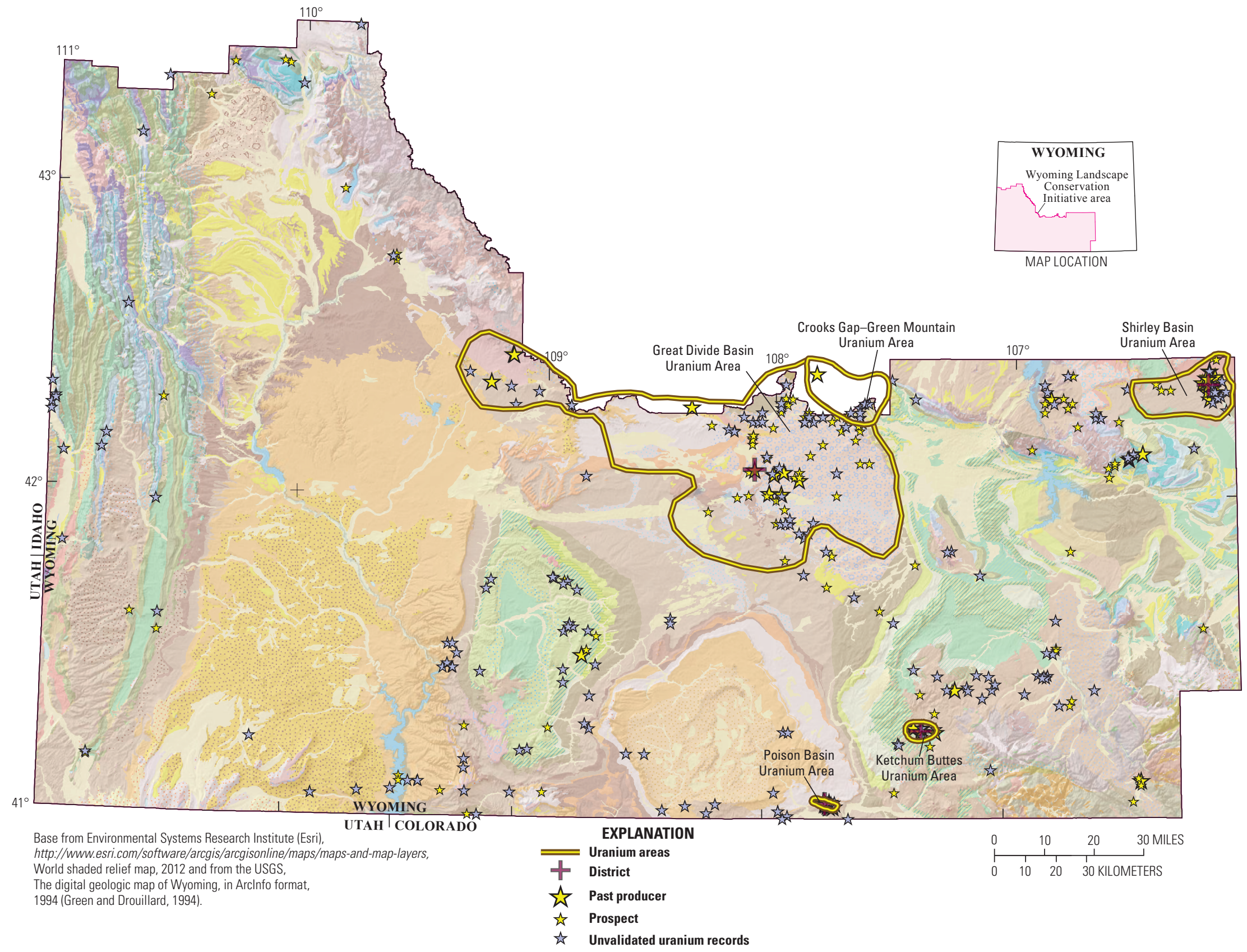

Figure 7. Map of uranium mineralized areas within the WLCI study area (from Wilson, in press). 
Reviews of the JAB and Antelope projects in the northeastern part of Great Divide Basin submitted in 2008 are deferred (U.S.NRC, 2012a) as is the proposed project in Bison Basin (West Alkali Creek, U.S.NRC, 2012b). Lost Soldier, submitted to the U.S.NRC as a satellite to the Lost Creek project, seems to be inactive as well (U.S.NRC, 2012c).

There was a proposed project (Juniper Ridge) in Poison Basin (BLM, 2012b). A plan of operations (BLM, 2012b) and notice inviting comment until June 8, 2012 (BLM, 2012c) were posted on the BLM website. Crosshair Energy Corp. (now Jet Metals Corp.) filed an NI 43-101 Technical Report with SEDAR (System for Electronic Document Analysis and Retrieval for the Canadian Securities Administrators) on Feb. 21, 2012 (Beahm, 2012). The property transferred to Energy Fuels Inc., when it acquired Strathmore Minerals Corp. in Aug. 2013 (Energy Fuels, Inc., 2014).

In addition to these recent projects, exploration activity through time can be assessed by viewing claim data (Wilson, in press). These data are a subset of the compilation by Causey (2007, rev. 2011) and are included in the interactive map portion of this publication. In the eastern part of Great Divide Basin there were many claims in 1976, but very few by 1985 due to price collapses (as a result of the Three Mile Island and Chernobyl incidents). There have been slight increases in activity since 2005 due to advances in in-situ recovery technology.

\section{Solar}

In the United States there has been an impetus to increase power generation from renewable resources, and recent growth in solar energy has been strong. The EIA data show increasing power generation from solar facilities (of at least 1 megawatt capacity) over the last three years grew by 111 percent in the United States. Generation from distributed solar facilities smaller than 1 megawatt has also increased rapidly. However, coal, natural gas, and nuclear remain the three biggest power generation sources at about 43 percent, 24 percent, and 19 percent, respectively (EIA, 2011).

The National Renewable Energy Laboratory (NREL) performs solar radiation research (http://www.nrel.gov/ solar_radiation/) and monitors solar radiation and other meteorological data continuously at the Solar Radiation Research Laboratory (SRRL, http://www.nrel.gov/solar_radiation/ facilities.html). Optimal siting of solar energy systems requires knowledge of the solar resource characteristics at any given location (NREL, 2011).

Solar resource map products generated by the SRRL provide visual presentations of the solar resource characteristics and can be used to identify areas optimal for solar resource potential within the WLCI study area (fig. 8). The solar data layer included in the interactive map provides monthly and annual averages of daily total solar resource over surface cells of 0.1 degrees in both latitude and longitude, or about $10 \mathrm{~km}$ in size (NREL, 2010).
The solar resource potential model uses hourly radiance images from geostationary weather satellites, daily snow cover data, and monthly averages of atmospheric water vapor, trace gases, and the amount of aerosols in the atmosphere to calculate the hourly total insolation (sun and sky) falling on a horizontal surface (NREL, 2010). More detailed information is included in the metadata document describing the solar data in this publication.

\section{Geographic Information System (GIS) Layer Information}

The emphasis of this report is the GIS data package. Part B of the Energy Map of Southwestern Wyoming (pl. 1) incorporates many energy resource-related features for analysis and display in the form of maps, reports and charts. Plate 1 was created directly from the ArcMap project (Esri, 2000), that consequently contains a number of additional layers not shown on the hardcopy map. Each of the layers included in the ArcMap project are described in table 1 with hyperlinks to source data information websites. Not described are base geographic data and cartography, including county lines, lakes and rivers, and map annotations (largely from Gregory and others, 2010). Further instructions for accessing the "interactive" map are included in the next section, "Downloadable Data and the Interactive Map."

Link to table 1.

\section{Downloadable Data and the Interactive Map}

Part B of the Energy Map of Southwestern Wyoming is available as a GIS map project in both ArcMap (MXD) and ArcReader (PMF) formats, and can be downloaded at http://dx.doi.org.10.3133/ds843. The map project enables visualization and analysis of energy resources data in ways that reveal relationships, patterns, and trends more effectively than with the static PDF map. The GIS map publishing process uses the ArcMap document (MXD) to create a formatted file called a published map file (PMF). ArcGIS Publisher (Esri, 2008a) generates the PMF from the MXD, and packages the included data with the PMF file for easy distribution. PMFs can be used to view, navigate, or print GIS maps using any ArcGIS (Esri, 2000) desktop product, including ArcMap and the free ArcReader (Esri, 2008b) application. Access to the MXD requires ArcGIS 10 or later software (Esri, 2000).

For the previously published data, the accompanying metadata have been retained as published. The difference between the original published data and the version included here is that, other than the oil and gas assessment units (AU), the features have been clipped to the WLCI boundary. Although they appear clipped to the WLCI boundary on the map, each of the AU area extents in their entirety are included in the geodatabase. 


\section{Concentrating Solar Power Resource}

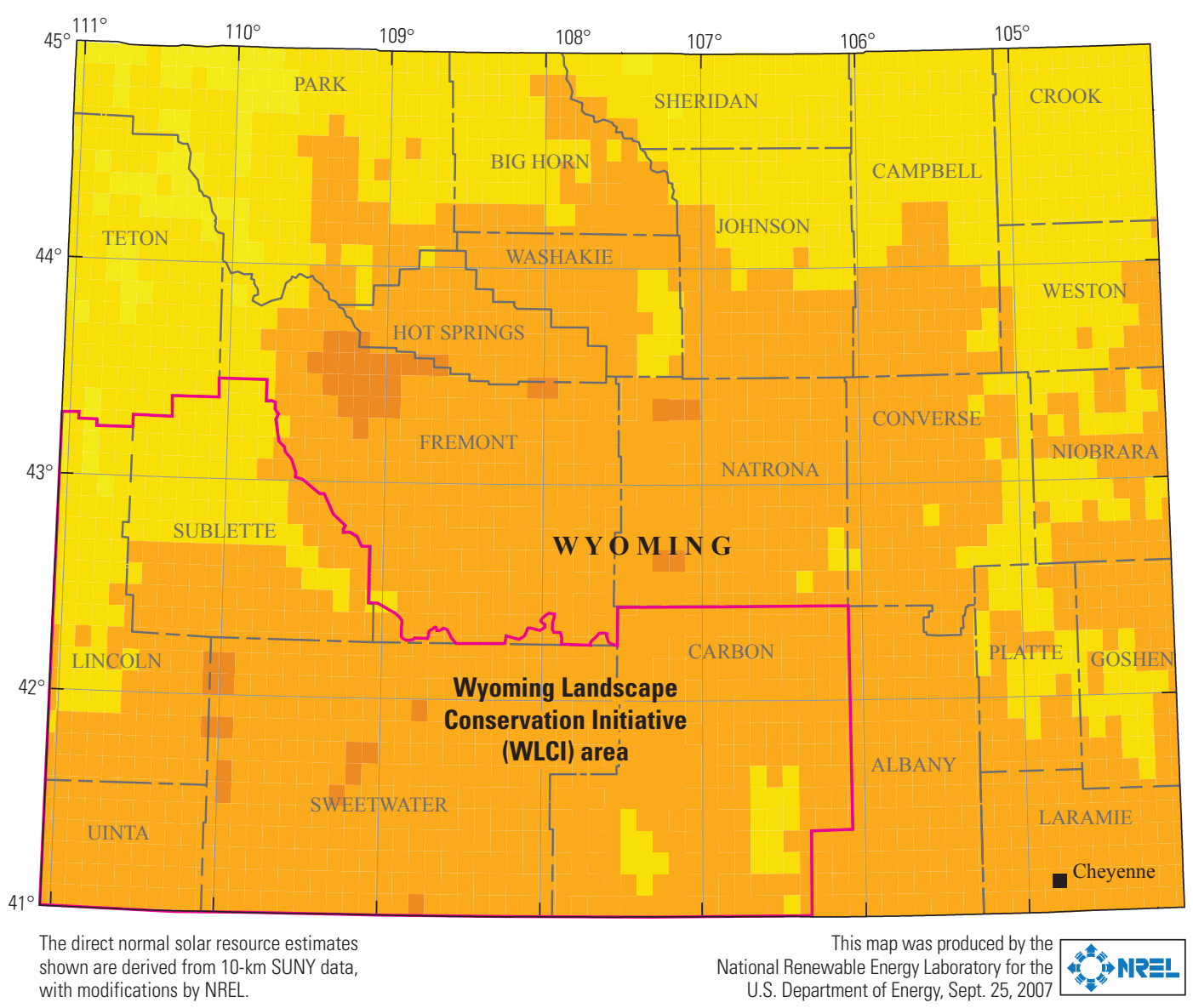

EXPLANATION

Units in kilowatt hours

per square meter per day (kWh/m²/Day)

$>9$

8.5-9.0

$8.0-8.5$

7.5-8.0

$7.0-7.5$

6.5-7.0

6.0-6.5

$5.5-6.0$

$5.0-5.5$

$4.5-5.0$

$4.0-4.5$

3.5-4.0

$3.0-3.5$

2.5-3.0

$2.0-2.5$

$<2$

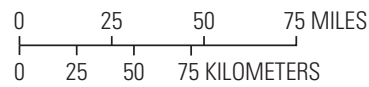

Figure 8. Map showing direct-normal solar resource estimates for Wyoming (modified from U.S. Department of Energy, National Renewable Energy Laboratory, 2007). SUNY; State University of New York; NREL, National Renewable Energy Laboratory.

All data are stored in a file-based geodatabase (WLCI EnergyMapB.gdb) using the World Geodetic System (WGS) 1984 projection, a standard projection for distributing geospatial data. For the ArcGIS.com web services (Esri, 2009), data descriptions, sources, and credits are stored as layer properties.

\section{Summary}

This report and GIS project assemble and organize oil and gas, oil shale, uranium, and solar data to assess what is known about southwestern Wyoming's energy resources. It also archives and disseminates this information to collaborators and the public, and provides an online resource for ongoing and future WLCI research. An integrated assessment (IA) methodology was initiated to synthesize what has been learned about WLCI systems to date, and to develop associated decision tools, maps, and a comprehensive report (Bowen and others, 2010). To advance the objectives of the USGS and the WLCI, the Energy Map of Southwestern Wyoming, Part B, represents decades of research by the USGS, WSGS, and others, and can facilitate landscape-level science assessments, and informed resource management decisions. Energy maps, data, documentation and spatial data processing capabilities for this report are available at http://pubs.usgs.gov/ds/843 and http://dx.doi.org/10.3133/ds843.

\section{Acknowledgments}

Funding for the Energy Map of Southwestern Wyoming was provided by the USGS WLCI project. The uranium map of Wyoming (Gregory and others, 2010) and the oil and gas fields map of Wyoming (De Bruin, 2007) were originally published as GIS layers, and some of the data, symbology, and annotations included in the ArcMap project and on plate 1 were taken with permission, directly from those sources. We acknowledge the USGS assessment teams, the list of which is too lengthy to include here (see table 1), for the comprehensive geologic studies that went into assessing undiscovered oil and gas resources, and in-place oil shale resources of this area. The manuscript and GIS benefited from the thoughtful reviews of Thomas Finn, James Stafford, and David Ferderer; their evaluations and suggested revisions are greatly appreciated. Lisa Binder is gratefully acknowledged for editorial review. 


\section{References}

Adobe Systems Incorporated, 2010, Adobe Reader 9: Adobe Systems Inc., San Jose, Calif. Accessed on Jan. 27, 2012 at http://www.adobe.com/products/reader/?promoid=DJDXD.

Beahm, D.L., 2012, Juniper Ridge Uranium Project, Carbon County Wyoming, USA, NI 43-101 Technical Report prepared for Crosshair Energy Corp.: Lakewood, Colo., Energy Fuels Inc., 51 p. Available at http://www.energyfuels.com/_resources/ Juniper_Ridge_Feb2012.pdf

Bierei, M.A., 1987, Hydrocarbon maturation, source rock potential, and thermal evolution of the Late Cretaceous and early Tertiary rocks of the Hanna Basin, southeast Wyoming: Laramie, Wyo., University of Wyoming, M.S. thesis, $151 \mathrm{p}$.

Biewick, L.R.H., 2009, Oil and gas development in southwestern Wyoming-Energy data and services for the Wyoming Landscape Conservation Initiative (WLCI): U.S. Geological Survey Data Series 437, http://pubs.usgs.gov/ds/437/.

Biewick, L.R.H., 2011, Geodatabase of Wyoming statewide oil and gas drilling activity to 2010: U.S. Geological Survey Data Series 625, http://pubs.usgs.gov/ds/625/.

Biewick, L.R.H., and Jones, N.R., 2012, Energy map of southwestern Wyoming, Part A-Coal and wind: U.S. Geological Survey Data Series 683, 18 p. pamphlet, 5 pls., http://pubs.usgs.gov/ds/683/.

Birdwell, J.E., Mercier, T.J., Johnson, R.C., and Brownfield, M.E., 2013, In-place oil shale resources examined by grade in the major basins of the Green River Formation, Colorado, Utah, and Wyoming: U.S. Geological Survey Fact Sheet 2012-3145, 4 p., http://pubs.usgs.gov/fs/2012/3145/.

Blakey, R.C., 2010, Paleogeography and geologic evolution of North America, Images that track the ancient landscapes of North America, copyright Ron Blakey: Flagstaff, Ariz., Colorado Plateau Geosystems, Inc. Accessed on June 28, 2012 at http://cpgeosystems.com/indexl.html.

Boberg, W.W., 2010, The nature and development of the Wyoming uranium province: Society of Economic Geologists, Special Publication 15, p. 653-674.

Bowen, Z.H., Aldridge, C.L., Anderson, P.J., Assal, T.J., Biewick, L.R.H., Blecker, S.W., Bristol, Sky, Carr, N.B., Chalfoun, A.D., Chong, G.W., Diffendorfer, J.E., Fedy, B.C., Garman, S.L., Germaine, Stephen, Grauch, R.I., Holloway, JoAnn, Homer, Collin, Kauffman, M.J., Keinath, Douglas, Latysh, Natalie, Manier, Daniel, McDougal, R.R., Melcher, C.P., Miller, K.A., Montag, Jessica, Nutt, C.J., Potter, C.J., Sawyer, Hall, Schell, Spencer, Shafer, S.L., Smith, D.B., Stillings, L.L., Tuttle, Michele, and Wilson, A.B., 2010, U.S. Geological Survey science for the Wyoming Landscape Conservation Initiative - 2009 Annual Report: U.S. Geological Survey Open-File Report 2010-1231, 106 p., http://pubs.usgs.gov/of/2010/1231/.
Bradley, W.H., 1964, Geology of Green River Formation and associated Eocene rocks in southwestern Wyoming and adjacent parts of Colorado and Utah: U.S. Geological Survey Professional Paper 496-A, 86 p.

Brown, David, 2007, Shales add to Wyoming portfolio: American Association of Petroleum Geologists Explorer, May 2007. Accessed on June 28, 2012 at http://archives.aapg.org/explorer/ 2007/05may/05explorer07.pdf.

Brownfield, M.E., Self, J.G., and Mercier, T.J., 2008, Fischer assay histograms of oil-shale drill cores and cuttings from the Great Divide, Green River, and Washakie Basins, Southwestern Wyoming, chap. 2 of U.S. Geological Survey Oil Shale Assessment Team, eds., Fischer assays of oil-shale drill cores and rotary cuttings from the Greater Green River Basin, Southwestern Wyoming: U.S. Geological Survey Open-File Report 2008-1152, 12 p., http://pubs.usgs.gov/ of/2008/1152/downloads/Chapter2/Chapter2.pdf.

Burtner, R.L., Nigrini, Andrew, and Donelick, R.A., 1994, Thermochronology of Lower Cretaceous source rocks in the Idaho-Wyoming thrust belt: American Association of Petroleum Geologists Bulletin, v. 78, p. 1613-1636.

Burtner, R.L., and Warner, M.A., 1984, Hydrocarbon generation in Lower Cretaceous Mowry and Skull Creek Shales of the Northern Rocky Mountain area, in Woodward, Jane, Meissner, F.F., and Clayton, J.L., eds., Hydrocarbon source rocks of the Greater Rocky Mountain Region: Rocky Mountain Association of Geologists, p. 449-467.

Byers, C.W., and Larson, D.W., 1979, Paleoenvironments of Mowry Shale (Lower Cretaceous), western and central Wyoming: American Association of Petroleum Geologists Bulletin, v. 63, p. 354-375.

Cardinal, D.F., and Stewart, W.W., 1979, Wyoming oil and gas fields symposium, Greater Green River basin: Wyoming Geological Association, 428 p.

Carroll, A.R., and Bohacs, K.M., 2001, Lake-type controls on petroleum source rock potential in nonmarine basins: American Association of Petroleum Geologists Bulletin, v. 85 , no. 6, p. 1033-1053.

Causey, J. Douglas, 2007 [rev. 2011], Mining claim activity on Federal land in the United States: U.S. Geological Survey Data Series 290, http://pubs.usgs.gov/ds/2007/290/.

Claypool, G.E., Love, A.H., and Maughan, E.K., 1978, Organic geochemistry, incipient metamorphism and oil generation in black shale members of the Permian Phosphoria Formation, Western Interior United States: American Association of Petroleum Geologists Bulletin, v. 62, no. 1, p. $98-120$.

Dahlkamp, F.J., 2010, Uranium deposits of the world-USA and Latin America, Wyoming Basins: SpringerLink, p. 149-207, http://www.springerlink.com/content/x74946/?MUD $=M P$. [Note: the bibliography, p. 381-414 is not available online]. 
Davis. J.C., 1970, Petrology of Cretaceous Mowry Shale of Wyoming: American Association of Petroleum Geologists Bulletin, v. 54, p. 487-502.

De Bruin, R.H., 2001, Wyoming's natural gas resourcesPast, present, and future, Wyoming Gas Resources and Technology, in 52nd field conference guidebook, 2001: Wyoming Geological Association, p. 33-39. Accessed on June 28, 2012 at $h$ ttp://search.datapages.com/data/wga/ data/066/066001/33_wga0660033.htm?q=\%2Btext\%3A\%2 2lake+ridge $\% 22$.

De Bruin, R.H., 2007, Oil and gas fields map of Wyoming: Wyoming State Geological Survey Map Series MS-55, http://www.wsgs.uwyo.edu/.

Dickinson, W.R., Klute, M.A., Hayes, M.J., Janecke, S.U., Lundin, E.R., McKittrick, M.A., and Olivares, M.D., 1988, Paleographic and paleotectonic setting of Laramide sedimentary basins in the central Rocky Mountain region: Geological Society of America Bulletin, v. 100, p. 1023-1039.

Dow, W.C., 1977, Kerogen studies and geological interpretations: Journal of Geochemical Exploration, v. 7, p. 79-99.

Dyman, T.S., and Condon, S.M., 2007, 2005 Geologic assessment of undiscovered oil and gas resources, Hanna, Laramie, and Shirley Basins Province, Wyoming and Colorado, chap. 2 of U.S. Geological Survey Hanna, Laramie, and Shirley Basins Province Assessment Team, eds., Petroleum systems and geologic assessment of undiscovered oil and gas, Hanna, Laramie, and Shirley Basins Province, Wyoming,: U.S. Geological Survey Digital Data Series 69-K, 68 p., http://pubs.usgs.gov/ $d d s / d d s-069 / d d s-069-k / R E P O R T S / 69 \_K \_C H \_2 . p d f$.

Dyman, T.S., Condon, S.M., Ahlbrandt, T.S., Charpentier, R.R.., Cook, T.A., Klett, T.R., Lewan, M.D., Lillis, P.G., Pawlewicz, M.J., Pollastro, R.M., and Schenk, C.J., 2005, 2005 Assessment of undiscovered oil and gas resources in Hanna, Laramie, and Shirley Basins Province, Wyoming: U.S. Geological Survey Fact Sheet 2005-3125, 4 p., http://pubs.usgs.gov/fs/2005/3125/.

Dyni, J.R., Mercier, T.J., and Brownfield, M.E., 2008, Analyses of oil shale samples from core holes and rotary-drilled wells from the Green River Formation, Southwestern Wyoming, chap. 1 of U.S. Geological Survey Oil Shale Assessment Team, eds., Fischer assays of oil-shale drill cores and Rotary Cuttings From the Greater Green River Basin, Southwestern Wyoming: U.S. Geological Survey Open-File Report 2008-1152, 18 p. http://pubs.usgs.gov/of/2008/1152/ downloads/Chapter1/Chapter1.pdf.

Energy Fuels Inc., 2014, Juniper Ridge: Lakewood, Colo., Energy Fuels, Inc. Available at http://www.energyfuels.com/ development_projects/juniper_ridge/.

Esri, 2000, ArcGIS: Redlands, Calif., Environmental Systems Research Institute, Inc. Accessed on Jan. 27, 2012 at $h t t p: / / w w w . e s r i . c o m / s o f t w a r e / a r c g i s /$.
Esri, 2008a, ArcPublisher: Redlands, Calif., Environmental Systems Research Institute, Inc. Accessed on Jan. 27, 2012

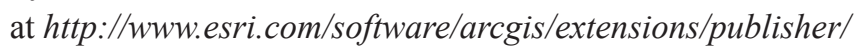
index.html and http://www.esri.com/software/arcgis/ extensions/publisher/publishing.html.

Esri, 2008b, ArcReader: Redlands, Calif., Environmental Systems Research Institute, Inc. Accessed on Jan. 27, 2012 at http://www.esri.com/software/arcgis/arcreader/download.html.

Esri, 2009, ArcGIS online: Redlands, Calif., Environmental Systems Research Institute, Inc. Accessed on Jan. 27, 2012 at http://www.esri.com/software/arcgis/arcgisonline/index.html.

Esri, 2012, Geodatabase: Redlands, Calif., Environmental Systems Research Institute, Inc. Accessed on Jan. 27, 2012 at http://www.esri.com/software/arcgis/geodatabase/index.html.

Finn, T.M., and Johnson, R.C., 2005a, The Hilliard-BaxterMancos total petroleum system, Southwestern Wyoming Province, chap. 7 of USGS Southwestern Wyoming Province Assessment Team, eds., Petroleum systems and geologic assessment of oil and gas in the Southwestern Wyoming Province, Wyoming, Colorado, and Utah: U.S. Geological Survey Digital Data Series 69-D, 22 p. http://pubs.usgs.gov/ $d d s / d d s-069 / d d s-069-d / R E P O R T S / 69+D \_C H \_7 . p d f$

Finn, T.M., and Johnson, R.C., 2005b, Niobrara total petroleum system (503703) in the Southwestern Wyoming Province, chap. 6 of USGS Southwestern Wyoming Province Assessment Team, eds., Petroleum systems and geologic assessment of oil and gas in the Southwestern Wyoming Province, Wyoming, Colorado, and Utah: U.S. Geological Survey Digital Data Series 69-D, 31 p., http://pubs.usgs.gov/dds/dds-069/ dds-069-d/REPORTS/69_D_CH_6.pdf

Finn, T.M., Johnson, R.C., and Roberts, S.B., 2005, The Mesaverde-Lance-Fort Union Composite total petroleum system, Southwestern Wyoming Province, chap 10 of U.S. Geological Survey Southwestern Wyoming Province Assessment Team, eds., Petroleum systems and geologic assessment of oil and gas in the Southwestern Wyoming Province, Wyoming, Colorado, and Utah: U.S. Geological Survey Digital Data Series 69-D, 9 p., http://pubs.usgs.gov/dds/dds-069/dds-069-d/ REPORTS/69_D_CH_10.pdf

Gill, J.R., Merewether, E.A., and Cobban, W.A., 1970, Stratigraphy and nomenclature of some Upper Cretaceous and lower Tertiary rocks in south-central Wyoming: U.S. Geological Survey Professional Paper 667, 53 p.

Grabowski, G.J., Jr., and Bohacs, K.M., 1996, Controls on composition and distribution of lacustrine organic-rich rocks of the Green River Formation, Wyoming [abs.], in 1996 Annual Convention, San Diego, Calif.: American Association of Petroleum Geologists and Society of Economic Paleontologists and Mineralogists, Annual Meeting Abstracts, v. 5, p. 55. 
Green, G.N., and Drouillard, P.H., 1994, The digital geologic map of Wyoming in ARC/INFO format: U.S. Geological Survey Open-File Report 94-425., http://pubs.usgs.gov/ of/1994/0425/.

Gregory, R.W., Jones, R.W., and Cottinghham, K.D., 2010 Uranium map of Wyoming: Wyoming State Geological Survey Map Series 94, scale 1:500,000, http://sales.wsgs.uwyo.edu/ catalog/index.php.

Gries, Robbie, Dolson, J.C., and Raynolds, R.G.H., 1992, Structural and stratigraphic evolution and hydrocarbon distribution, Rocky Mountains foreland, in Macqueen, R.W., and Leckie, D.A., eds., Foreland basins and fold belts: American Association of Petroleum Geologists Memoir 55, p. 395-425.

Gruver, Mead, 2010, Wyoming approves "fracking" disclosure rules, in The Seattle Times, June 8, 2010: Cheyenne, Wyo., Associated Press, The Seattle Times. Available at http://seattletimes.com/html/businesstechnology/2012062537_ apwyoilgasrules.html.

Hansen, D.E., 1986, Laramide tectonics and deposition of the Ferris and Hanna Formations, south-central Wyoming: American Association of Petroleum Geologists Memoir 41, p. 481-495.

Hettinger, R.D., Honey, J.G., and Nichols, D.J., 1991, Chart showing correlations of Upper Cretaceous Fox Hills Sandstone and Lance Formation, and lower Tertiary Fort Union, Wasatch, and Green River Formations, from the eastern flank of the Washakie Basin to the southeastern part of the Great Divide Basin, Wyoming: U.S. Geological Survey Miscellaneous Investigations Map I-2151, 1 sheet.

Hettinger, R.D., and Roberts, L.N.R., 2005, Lewis total petroleum system of the Southwestern Wyoming Province, Wyoming, Colorado, and Utah, chap. 9 of U.S. Geological Survey Southwestern Wyoming Province Assessment Team, eds., Petroleum systems and geologic assessment of oil and gas in the Southwestern Wyoming Province, Wyoming, Colorado, and Utah: U.S. Geological Survey Digital Data Series 69-D, 43 p., http://pubs.usgs.gov/dds/dds-069/ dds-069-d/REPORTS/69_D_CH_9.pdf.

Hill, D.G., Curtis, J.B., and Lillis, P.G., 2008, Update on North America shale-gas exploration and development, in Hill, D.G., Lillis, P.G., and Curtis, J.B., eds., 2008 shale gas in the Rocky Mountains and beyond: Rocky Mountain Association of Geologists, 2008 Guidebook.

Hunt, J.M., 1979, Petroleum geochemistry and geology:

San Francisco, W.H. Freeman and Co., 617 p.

IHS Energy Group, 2001, PI/Dwights Plus U.S. Production and Well Data [includes data current as of Dec., 2000]: Englewood, Colo., IHS Energy Group, 15 Inverness Way East, D205, Englewood, Colo.
Johnson, E.A., 2003, Geologic assessment of the Phosphoria total petroleum system, Uinta-Piceance Province, Utah and Colorado, chap. 9 of U.S. Geological Survey UintaPiceance Assessment Team, eds., Petroleum systems and geologic assessment of oil and gas in the Uinta-Piceance Province, Utah and Colorado: U.S. Geological Survey Digital Data Series 69-B, 37 p., http://pubs.usgs.gov/dds/ $d d s-069 / d d s-069-b / R E P O R T S / C h a p t e r+9 . p d f$.

Johnson, E.A., 2005, Geologic assessment of undiscovered oil and gas resources in the Phosphoria total petroleum system, Southwestern Wyoming Province, Wyoming, Colorado, and Utah, chap. 4 of U.S. Geological Survey Southwestern Wyoming Province Assessment Team, eds., Petroleum systems and geologic assessment of oil and gas in the Southwestern Wyoming Province, Wyoming, Colorado, and Utah: U.S. Geological Survey Digital Data Series 69-D, 51 p., http://pubs.usgs.gov/dds/dds-069/dds-069-d/ REPORTS/69_D_CH_4.pdf.

Johnson, R.C., Finn, T.M., and Roberts, L.N.R., 2005, The Mesaverde total petroleum system, Southwestern Wyoming Province, chap. 8 of USGS Southwestern Wyoming Province Assessment Team, eds., Petroleum systems and geologic assessment of oil and gas in the Southwestern Wyoming Province, Wyoming, Colorado, and Utah: U.S. Geological Survey Digital Data Series 69-D, 43 p., http://pubs.usgs.gov/dds/

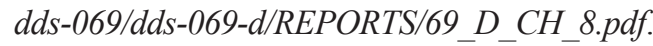

Johnson, R.C., Mercier, T.J., Brownfield, M.E., Pantea, M.P., and Self, J.G., 2009, Assessment of in-place oil shale resources of the Green River Formation, Piceance Basin, western Colorado: U.S. Geological Survey Fact Sheet 2009-3012, 6 p., http://pubs.usgs.gov/fs/2009/3012/ and http://energy.usgs.gov/OilGas/UnconventionalOilGas/ OilShale.aspx.

Johnson, R.C., Mercier, T.J., and Brownfield, M.E., 2011, Assessment of in-place oil shale resources of the Green River Formation, Greater Green River Basin in Wyoming, Colorado, and Utah: U.S. Geological Survey Fact Sheet 2011-3063, 4 p., http://pubs.usgs.gov/fs/2011/3063/.

Johnson, R.C., Mercier, T.J., Ryder, R.T., Brownfield, M.E., and Self, J.G., 2011, Assessment of in-place oil shale resources of the Eocene Green River Formation, Greater Green River Basin, Wyoming, Colorado, and Utah, chap. 1 of U.S. Geological Survey Oil Shale Assessment Team, eds., Oil shale resources of the Eocene Green River Formation, Greater Green River Basin, Wyoming, Colorado, and Utah: U.S. Geological Survey Digital Data Series 69-DD, 63 p., http://pubs.usgs.gov/dds/dds-069/ dds-069-dd/REPORTS/69_DD_CH_1.pdf.

Keller, E.R., and Thomaidis, N.D., 1971, Petroleum potential of southwestern Wyoming and adjacent areas, in Cram, I.H., ed., Future petroleum provinces of the United States-Their geology and potential: American Association of Petroleum Geologists Memoir 15, p. 656-672. 
Kirschbaum, M.A., and Roberts, L.N.R., 2005, Geologic assessment of undiscovered oil and gas resources of the Mowry composite total petroleum system, Southwestern Wyoming Province, Wyoming, Colorado, and Utah, chap. 5 of U.S. Geological Survey Southwestern Wyoming Province Assessment Team, eds., Petroleum systems and geologic assessment of oil and gas in the Southwestern Wyoming Province, Wyoming, Colorado, and Utah: U.S. Geological Survey Digital Data Series 69-D, 27 p., http://pubs.usgs.gov/ dds/dds-069/dds-069-d/REPORTS/69_D_CH_5.pdf.

Landon, S.M., Longman, M.W., and Luneau, B.A., 2001, Hydrocarbon source rock potential of the Upper Cretaceous Niobrara Formation, Western Interior Seaway of the Rocky Mountain region: The Mountain Geologist, v. 38, no. 1, p. $1-18$.

Law, B.E., 1984, Relationships of source-rock, thermal maturity, and overpressuring to gas generation and occurrence in low-permeability Upper Cretaceous and lower Tertiary rocks, Greater Green River Basin, Wyoming, Colorado and Utah, in Woodward, J., Meissner, F.F., and Clayton, J.L., eds., Hydrocarbon source rocks of the greater Rocky Mountain Region: Rocky Mountain Association of Geologists Guidebook, p. 469-490.

Law, B.E., 1996, Southwestern Wyoming Province (037), in Gautier, D.L., Dolton, G.L., Takahashi, K.I., and Varnes, K.L., eds., 1995 National assessment of United States oil and gas resources-Results, methodology, and supporting data: U.S. Geological Survey Digital Data Series DDS-30, release 2, http://certmapper.cr.usgs.gov/data/noga95/ prov37/text/prov37.pdf.

Law, B.E., 2002, Basin-centered gas systems: American Association of Petroleum Geologists Bulletin, v. 86, no. 11, p. 1891-1919.

Law, B.E., Spencer, C.W., Charpentier, R.R., Crovelli, R.A., Mast, R.F., Dolton, G.L., and Wandrey, C.J., 1989, Estimates of gas resources in overpressured low-permeability Cretaceous and Tertiary sandstone reservoirs, Greater Green River Basin, Wyoming, Colorado, and Utah, in Eisert, J.L., ed., Gas resources of Wyoming: Wyoming Geological Association Fortieth Field Conference Guidebook, p. 39-61.

Levine, J.R., 1993, Coalification-The evolution of coal as a source rock and reservoir rock for oil and gas, in Law, B.E., and Rice, D.D., eds., Hydrocarbons from coal: American Association of Petroleum Geologists Studies in Geology, no. 38 , p. 39-76.

Longman, M.W., Luneau, B.A., and Landon, S.M., 1998, Nature and distribution of Niobrara lithologies in the Cretaceous Western Interior Seaway of the Rocky Mountain region: The Mountain Geologist, v. 35, no. 4, p. 137-170.
Love, J.D., and Christiansen, A.C., 1985, Geologic map of Wyoming: U.S. Geological Survey, 3 sheets, scale 1:500,000.

Masters, J.A., 1979, Deep basin gas traps, western Canada: American Association of Petroleum Geologists Bulletin, v. 63 , no. 2, p. $152-181$.

Maughan, E.K., 1979, Petroleum source rock evaluation of the Permian Park City Group in the northeastern Great Basin, Utah, Nevada, and Idaho, in Newman, G.W., and Goode, H.D., eds., Basin and Range symposium: Rocky Mountain Association of Geologists and Utah Geological Association, p. 523-530.

Maughan, E.K., 1984, Geological setting and some geochemistry of petroleum source rocks in the Permian Phosphoria Formation, in Woodward, Jane, Meissner, F.F., and Clayton, J.L., eds., Hydrocarbon source rocks of the greater Rocky Mountain region: Rocky Mountain Association of Geologists, p. 281-294.

McDonald, R.E., 1972, Eocene and Paleocene rocks of the southern and central basins, in Mallory, W.W., ed., Geologic atlas of the Rocky Mountain Region: Rocky Mountain Association of Geologists, p. 243-256.

McKelvey, V.E., 1949, Geological studies of the Western Phosphate Field: Mining Transactions, v. 184, p. 271-279.

McKelvey, V.E., Williams, J.S., Sheldon, R.P., Cressman, E.R., Cheney, T.M., and Swanson, R.W., 1959, The Phosphoria, Park City, and Shedhorn Formations in the western phosphate field: U.S. Geological Survey Professional Paper 313-A, 47 p.

Mercier, T.J., Johnson, R.C., and Brownfield, M.E., 2011, In-place oil shale resources underlying Federal lands in the Green River and Washakie Basins, southwestern Wyoming: U.S. Geological Survey Fact Sheet 2011-3113, 2 p, http://pubs.usgs.gov/fs/2011/3113/.

Microsoft, Corp., 2007, Getting started with Excel 2007: Redmond, Wash., Microsoft Corp. Accessed on Jan. 27, 2012 at http://office.microsoft.com/en-us/support/getting-startedwith-microsoft-office-2007-FX101839657.aspx.

Miller, T.S., Crockett, F.J., and Hollis, S.H., 1992, Wyoming oil and gas fields symposium, Greater Green River Basin and Overthrust Belt: Wyoming Geological Association Symposium, $372 \mathrm{p}$.

Mitchell, S.D., 1961, Geology and occurrence of natural gas in Laramie and Hanna Basins, Wyoming, in Natural gases of North America, v. 1: American Association of Petroleum Geologists Memoir 9, p. 828-839.

Nehring Associates, 2011, Database-Significant oil and gas fields of the United States: Colorado Springs, Colo., Nehring Associates, Inc., http://www.nehringdatabase.com/ the_database.html. 
Perez, Richard, Ineichen, Pierre, Moore, Kathy, Kmiecik, Marek, Chain, Cyril, George, Ray, Vignola, Frank, 2002, A new operational satellite-to-irradiance model-Description and validation: Solar Energy (73:5); p. 307-317. Accessed on June 28, 2012 at http://www.asrc.cestm.albany.edu/ perez/publications/Solar\%20Resource\%20Assessment\%20 and\%20Modeling/Papers\%20on\%20Resource\%20 Assessment\%20and\%20Satellites/A\%20New\%20 Operational\%20Satellite\%20irradiance\%20model-02.pdf.

Perman, R.C., 1990, Depositional history of the Maastrichtian Lewis Shale in south-central Wyoming-Deltaic and interdeltaic, marginal marine through deep-water marine, environments: American Association of Petroleum Geologists Bulletin, v. 74, no. 11, p. 1695-1717.

Pyles, D.R., 2000, A high-frequency sequence stratigraphic framework for the Lewis Shale and Fox Hills Sandstone, Great Divide and Washakie basins, Wyoming: Golden, Colo., Colorado School of Mines M.S. thesis, 261 p.

Roberts, S.B., 2005a, Geologic assessment of undiscovered petroleum resources in the Lance-Fort Union composite total petroleum system, Southwestern Wyoming Province, Wyoming and Colorado, chap. 11 of U.S. Geological Survey Southwestern Wyoming Province Assessment Team, eds., Petroleum systems and geologic assessment of oil and gas in the Southwestern Wyoming Province, Wyoming, Colorado, and Utah: U.S. Geological Survey Digital Data Series 69-D, 45 p., http://pubs.usgs.gov/dds/dds-069/dds-069-d/ REPORTS/69_D_CH_11.pdf.

Roberts, S.B., 2005b, Geologic assessment of undiscovered petroleum resources in the Wasatch-Green River composite total petroleum system, Southwestern Wyoming Province, Wyoming and Colorado, and Utah, chap. 12 of U.S. Geological Survey Southwestern Wyoming Province Assessment Team, eds., Petroleum systems and geologic assessment of oil and gas in the Southwestern Wyoming Province, Wyoming, Colorado, and Utah: U.S. Geological Survey Digital Data Series 69-D, 26 p., http://pubs.usgs.gov/dds/dds-069/ $d d s-069-d / R E P O R T S / 69 \_D \_C H \_12 . p d f$.

Roberts, L.N.R., and Kirschbaum, M.A., 1995, Paleogeography of the Late Cretaceous of the western interior of middle North America - Coal distribution and sediment accumulation: U.S. Geological Survey Professional Paper 1561, 115 p., http://pubs.usgs.gov/pp/1561/report.pdf.

Roberts, L.N.R., Kirschbaum, M.A., and McCabe, P.J., 1995, Paleogeography of the Late Cretaceous of the western interior of middle North America: U.S. Geological Survey poster, http://energy.cr.usgs.gov/coal_poster/cretcoals/ cret.coals.html.
Roberts, L.N.R., Lewan, M.D., and Finn, T.M., 2005, Burial history, thermal maturity, and oil and gas generation history of petroleum systems in the Southwestern Wyoming Province, Wyoming, Colorado, and Utah, chap. 3 of U.S. Geological Survey Southwestern Wyoming Province Assessment Team, eds., Petroleum systems and geologic assessment of oil and gas in the Southwestern Wyoming Province, Wyoming, Colorado, and Utah: U.S. Geological Survey Digital Data Series 69-D, 29 p., http://pubs.usgs.gov/dds/dds-069/ dds-069-d/REPORTS/69_D_CH_3.pdf.

Roehler, H.W., 1990, Stratigraphy of the Mesaverde Group in the central and eastern Greater Green River Basin, Wyoming, Colorado, and Utah: U.S. Geological Survey Professional Paper 1508, 52 p.

Roehler, H.W., 1992, Description and correlation of Eocene rocks in stratigraphic reference sections for the Green River and Washakie Basins, southwest Wyoming: U.S. Geological Survey Professional Paper 1506-D, 83 p.

Ryder, R.T., 1988, Greater Green River Basin, in Sloss, L.L., ed., Sedimentary cover-North American craton, U.S.: Geological Society of America, The geology of North America, volume D-2, p. 154-165.

Sheldon, R.P., 1963, Physical stratigraphy and mineral resources of Permian rocks in western Wyoming: U.S. Geological Survey Professional Paper 313-B, 273 p.

Surdam, R.C., Jiao, Zunsheng, De Bruin, R.H., and Bentley, R.D., 2010, Shale gas potential of the Mowry Shale in Wyoming Laramide basins: Wyoming State Geological Survey challenges in geologic resource development no. 9., Accessed on Nov. 30, 2012 at http://sales.wsgs.uwyo.edu/ catalog/product_info.php?cPath $=2 \&$ products_id $=3311$.

Swanson, R.W., McKelvey, V.E., and Sheldon, R.P., 1953, Progress report on investigations of western phosphate deposits: U.S. Geological Survey Circular 297, 16 p.

Tyler, Roger, Kaiser, W.R., Scott, A.R., Hamilton, D.S., and Ambrose, W.A., 1995, Geologic and hydrologic assessment of natural gas from coal-Greater Green River, Piceance, Powder River, and Raton Basins, Western United States: Bureau of Economic Geology and the Gas Research Institute Report of Investigations no. 228, 219 p.

U.S. Bureau of Land Management (BLM), 2006, EPCA Phase II Inventory, Energy Policy Act of 2005, Energy Policy and Conservation Act of 2000: U.S. Bureau of Land Management, accessed June 28, 2012 at $h t t p: / / w w w . b l m . g o v / e p c a /$.

U.S. Bureau of Land Management (BLM), 2010, Energy and minerals data theme: U.S. Bureau of Land Management, accessed on June 28, 2012 at http://www.blm.gov/wy/st/en/ resources/public_room/gis/datagis/themes/mineralgis.html.

U.S. Bureau of Land Management (BLM), 2011, Statewide data-Wyoming surface, mineral status and Nebraska BLM lands: U.S. Bureau of Land Management, accessed May 2, 2011, at http://www.blm.gov/wy/st/en/resources/ public_room/gis/datagis/state/state-own.html. 
U.S. Bureau of Land Management (BLM), 2012a, Lost Creek uranium in situ recovery project: U.S. Bureau of Land Management, accessed July 17, 2012 at http://www.blm.gov/wy/ st/en/info/NEPA/documents/rfo/lostcreek.html.

U.S. Bureau of Land Management (BLM), 2012b, Juniper Ridge uranium exploration project: U.S. Bureau of Land Management, accessed July 17, 2012 at $h t t p: / / w w w . b l m . g o v /$ wy/st/en/info/NEPA/documents/rfo/juniper_ridge.html.

U.S. Bureau of Land Management (BLM), 2012c, BLM Rawlins field office seeking comment on the Juniper Ridge uranium project: U.S. Bureau of Land Management, Rawlins Field Office, accessed July 17, 2012 at http://www.blm.gov/ wy/st/en/info/news_room/2012/may/10rfo-juniper.html.

U.S. Department of Energy, National Renewable Energy Laboratory (NREL), 2007, Dynamic maps, GIS data, and analysis tools - Concentrating solar power resource, Wyoming: U.S. Department of Energy, National Renewable Energy Laboratory, accessed on June 28, 2012 at $h t t p: / /$ www.nrel.gov/gis/pdfs/eere_csp/eere_csp_h_wyoming.pdf.

U.S. Department of Energy, National Renewable Energy Laboratory (NREL), 2010, Dynamic maps, GIS data, and analysis tools - Solar data, Lower 48 DNI 10km resolution 1998 to 2005: U.S. Department of Energy, National Renewable Energy Laboratory, accessed on June 28, 2012 at http://www.nrel.gov/gis/data_solar.html.

U.S. Department of Energy, National Renewable Energy Laboratory (NREL), 2011, Science \& Technology, Solar Research: U.S. Department of Energy, National Renewable Energy Laboratory, accessed on Aug. 23, 2012 at http://www.nrel.gov/solar/.

U.S. Department of Energy (DOE), Department of the Interior Bureau of Land Management (BLM), Department of Agriculture Forest Service (USFS), and Department of Defense (DoD), 2010, West-wide energy corridor programmatic EIS information center: U.S. Department of Energy, Office of NEPA (National Environmental Policy Act) Policy and Compliance (EH-42), accessed June 28, 2012 at http://corridoreis.anl.gov/index.cfm.

U.S. Department of the Interior, U.S. Department of Agriculture, and U.S. Department of Energy, 2006, Scientific inventory of onshore federal lands' oil and gas resources and the extent and nature of restrictions or impediments to their development-Phase II cumulative inventory-Northern Alaska, Montana thrust belt, Powder River basin, Wyoming thrust belt, Greater Green River basin, Denver basin, Uinta-Piceance basin, Paradox/San Juan basins, Appalachian basin, Black Warrior basin, Florida peninsula: Bureau of Land Management, accessed June 28, 2012, at http://www.blm.gov/epca/.

U.S. Energy Information Administration (EIA), 2009a, Top 100 U.S. oil \& gas fields by 2009 proved reserves: U.S. Department of Energy, accessed on June 28, 2012 at http://www.eia.doe.gov/oil_gas/rpd/topfields.pdf.
U.S. Energy Information Administration (EIA), 2010, U.S. States, Wyoming State profile and energy estimatesProfile overview: U.S. Department of Energy, accessed on Jan. 27, 2012 at http://www.eia.doe.gov/state/state_energy_ profiles.cfm? sid $=W Y$.

U.S. Energy Information Administration (EIA), 2011, Today in energy: U.S. Department of Energy, accessed on June 28, 2012 at http://www.eia.gov/todayinenergy/ detail.cfm? id $=3970$.

U.S. Geological Survey, 2012, Mineral Resources online spatial data, Mineral Resources Data System (MRDS): U.S. Geological Survey, http://mrdata.usgs.gov/mrds/.

U.S. Geological Survey Oil Shale Assessment Team, 2008, Fischer assays of oil-shale drill cores and rotary cuttings from the greater Green River basin, southwestern Wyoming: U.S. Geological Survey Open-File Report 2008-1152, 2 chaps., http://pubs.usgs.gov/of/2008/1152/.

U.S. Geological Survey Oil Shale Assessment Team, 2011, Oil shale resources of the Eocene Green River Formation, Greater Green River Basin, Wyoming, Colorado, and Utah: U.S. Geological Survey Digital Data Series 69-DD, 6 chap., pages variable., http://pubs.usgs.gov/dds/dds-069/ $d d s-069-d d /$.

U.S. Geological Survey Southwestern Wyoming Province Assessment Team, 2002, Assessment of undiscovered oil and gas resources of the Southwestern Wyoming Province, 2002: U.S. Geological Survey Fact Sheet 145-02, 2 p., http://pubs.usgs.gov/fs/fs-145-02/.

U.S. Geological Survey Southwestern Wyoming Province Assessment Team, 2005a, Petroleum systems and geologic assessment of oil and gas in the Southwestern Wyoming Province, Wyoming, Colorado, and Utah: U.S. Geological Survey Digital Data Series 69-D, http://pubs.usgs.gov/dds/ $d d s-069 / d d s-069-d /$.

U.S. Geological Survey Southwestern Wyoming Province Assessment Team, 2005b, The Southwestern Wyoming Province-Introduction to a geologic assessment of undiscovered oil and gas resources, chap. 2 of U.S. Geological Survey Southwestern Wyoming Province Assessment Team, eds., Petroleum systems and geologic assessment of oil and gas in the Southwestern Wyoming Province, Wyoming, Colorado, and Utah: U.S. Geological Survey Digital Data Series 69-D, http://pubs.usgs.gov/dds/dds-069/ $d d s-069-d / R E P O R T S / 69 \_D \_C H \_2 . p d f$.

U.S. Geological Survey Wyoming Thrust Belt Assessment Team, 2004, Assessment of undiscovered oil and gas resources of the Wyoming Thrust Belt Province, 2003: U.S. Geological Survey Fact Sheet 2004-3025, 2 p., http://pubs.usgs.gov/fs/2004/3025.

U.S. Nuclear Regulatory Commission (U.S.NRC), 2012, Locations of uranium recovery facilities: U.S. Nuclear Regulatory Commission, accessed July 17, 2012 at http://www.nrc.gov/ info-finder/materials/uranium/index.html. 
U.S. Nuclear Regulatory Commission (U.S.NRC), 2012a, JAB \& Antelope site - review deferred: U.S. Nuclear Regulatory Commission, available online at $h t t p: / / w w w . n r c . g o v /$ materials/uranium-recovery/license-apps/jab-antelope.html.

U.S. Nuclear Regulatory Commission (U.S.NRC), 2012b, 05/01/2008 Summary of meeting with Wildhorse Energy to discuss Wildhorse Energy's (Wildhorse's) planned west Alkali Creek uranium recovery site: U.S. Nuclear Regulatory Commission, accessed July 17, 2012 at http://pbadupws.nrc.gov/docs/ML0816/ML081610706.html.

U.S. Nuclear Regulatory Commission (U.S.NRC), 2012c, License applications for new uranium recovery facilities, expansions, restarts, and renewals: U.S. Nuclear Regulatory Commission, accessed July 17, 2012 at http://www.nrc.gov/ materials/uranium-recovery/license-apps.html.

Vincelette, R.R., and Foster, N.H., 1992, Fractured Niobrara of northwestern Colorado, in Schmoker, J.W., Coalson, E.B., and Brown, C.A., eds., Geological studies relevant to horizontal drilling - Examples from western North America: Rocky Mountain Association of Geologists Guidebook, p. 227-239.

Wallem, D.B., Surdam, R.C., and Steidtmann, J.R., 1981, Source rock analysis of the lower Cretaceous Bear River Formation, western Wyoming overthrust belt, in Reid, S.G., and Miller, D.D., eds., Energy resources of Wyoming: Wyoming Geological Association Thirty-Second Annual Field Conference Guidebook, p. 41-64.

Waples, D.W., 1980, Time and temperature in petroleum formation-Application of Lopatin's method to petroleum exploration: American Association of Petroleum Geologists Bulletin, v. 64, p. 916-926.
Warner, M.A., 1982, Source and time of generation of hydrocarbons in the fossil basin, western Wyoming thrust belt, in Powers, R.B., ed., Geologic studies of the Cordilleran Thrust Belt: Rocky Mountain Association of Geologists, p. 805-815.

Wilson, A.B., in press, Uranium in the Wyoming Landscape Conservation Initiative (WLCI) study area, Wyoming: U.S. Geological Survey Open-File Report 2014-1123, http://dx.doi.org/10.3133/of20141123.

Wilson, A.B., Klein, T.L., and Heran, W.D., 2001, Databases and simplified geology for mineralized areas, claims, mines and prospects in Wyoming: U.S. Geological Survey OpenFile Report 2001-497.

Wyoming Oil and Gas Conservation Commission (WOGCC), 2012. Accessed on October 9, 2012 at http://wogcc.state.wy.us/.

Wyoming State Geological Survey (WSGS), 2011, WSGS Oil and Gas: Wyoming State Geological Survey, accessed on June 28, 2012 at http://www.wsgs.uwyo.edu/Research/ Energy/Oil-Gas/Resources.aspx.

Wyoming State Geological Survey, 2012a, The origin of uranium deposits: Wyoming State Geological Survey, accessed July 13, 2012 at http://www.wsgs.uwyo.edu/Research/ Energy/Origin-Uranium.aspx.

Wyoming State Geological Survey, 2012b, Uranium: Wyoming State Geological Survey, accessed July 13, 2012 at http://www.wsgs.uwyo.edu/Research/Energy/Uranium.aspx.

Zainal, Zalina, 2001, Subsurface geology and petroleum systems of the lower Lewis Shale in the Sand Wash Basin, northwest Colorado: Golden, Colo., Colorado School of Mines Master's thesis, $191 \mathrm{p}$.

Publishing support provided by:

Denver Publishing Service Center, Denver, Colorado

For more information concerning this publication, contact:

Center Director, USGS Central Energy Resources Science Center

Box 25046, Mail Stop 939

Denver, CO 80225

(303) 236-1647

Or visit the Central Energy Resources Science Center Web site at: http://energy.usgs.gov/

This publication is available online at:

http://dx.doi.org/10.3133/ds843 
